\title{
Yields of hydrogen peroxide from the reaction of hydroxyl radical with organic compounds in solution and ice
}

\author{
T. Hullar and C. Anastasio \\ Department of Land, Air and Water Resources, University of California, Davis, One Shields Avenue, Davis, CA 95616, USA
}

Received: 31 January 2011 - Published in Atmos. Chem. Phys. Discuss.: 23 February 2011

Revised: 29 June 2011 - Accepted: 1 July 2011 - Published: 22 July 2011

\begin{abstract}
Hydrogen peroxide (HOOH) is a significant oxidant in atmospheric condensed phases (e.g., cloud and fog drops, aqueous particles, and snow) that also photolyzes to form hydroxyl radical $\left({ }^{\bullet} \mathrm{OH}\right) .{ }^{\bullet} \mathrm{OH}$ can react with organics in aqueous phases to form organic peroxyl radicals and ultimately reform $\mathrm{HOOH}$, but the efficiency of this process in atmospheric aqueous phases, as well as snow and ice, is not well understood. We investigate $\mathrm{HOOH}$ formation from $\cdot \mathrm{OH}$ attack on 10 environmentally relevant organic compounds: formaldehyde, formate, glycine, phenylalanine, benzoic acid, octanol, octanal, octanoic acid, octanedioic acid, and 2-butoxyethanol. Liquid and ice samples with and without nitrate (as an ${ }^{\circ} \mathrm{OH}$ source) were illuminated using simulated solar light, and $\mathrm{HOOH}$ formation rates were measured as a function of $\mathrm{pH}$ and temperature. For most compounds, the formation rate of $\mathrm{HOOH}$ without nitrate was the same as the background formation rate in blank water (i.e., illumination of the organic species does not produce $\mathrm{HOOH}$ directly), while formation rates with nitrate were greater than the water control (i.e., reaction of ${ }^{\circ} \mathrm{OH}$ with the organic species forms $\mathrm{HOOH}$ ). Yields of $\mathrm{HOOH}$, defined as the rate of $\mathrm{HOOH}$ production divided by the rate of ${ }^{\cdot} \mathrm{OH}$ production, ranged from essentially zero (glycine) to 0.24 (octanal), with an average of $0.12 \pm 0.05$ (95\% CI). $\mathrm{HOOH}$ production rates and yields were higher at lower $\mathrm{pH}$ values. There was no temperature dependence of the $\mathrm{HOOH}$ yield for formaldehyde or octanedioic acid between -5 to $20^{\circ} \mathrm{C}$ and ice samples had approximately the same $\mathrm{HOOH}$ yield as the aqueous solutions. In contrast, $\mathrm{HOOH}$ yields in formate solutions were higher at 5 and $10^{\circ} \mathrm{C}$ compared to -5 and $20^{\circ} \mathrm{C}$. Yields of $\mathrm{HOOH}$ in ice for solutions containing nitrate and either phenylalanine, benzoate, octanal, or octanoic acid were indistinguishable from zero. Our $\mathrm{HOOH}$
\end{abstract}

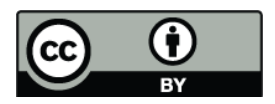

Correspondence to: C. Anastasio (canastasio@ucdavis.edu) yields were approximately half those found in previous studies conducted using $\gamma$-radiolysis, but this difference might be due to the much lower (and more environmentally relevant) $\mathrm{OH}$ formation rates in our experiments.

\section{Introduction}

Hydrogen peroxide $(\mathrm{HOOH})$ is a significant oxidant in atmospheric condensed phases such as cloud and fog drops, aqueous particles, and snow. For example, aqueous $\mathrm{HOOH}$ is one of the major oxidants that converts reduced sulfur (S(IV)) into sulfuric acid in the atmosphere (Finlayson-Pitts and Pitts, 2000) and it can also oxidize ketocarboxylic acids such as pyruvic acid (Carlton et al., 2006) and glyoxylic acid (Tan et al., 2009). The two sources of $\mathrm{HOOH}$ in cloud and fog drops and aqueous aerosol particles are partitioning from the gas phase and in situ photochemical production (Anastasio et al., 1994; Chameides and Davis, 1982; Moller, 2009). In addition to acting as an oxidant itself, $\mathrm{HOOH}$ in solution is also a source of highly reactive hydroxyl radical, both through direct photolysis (Chu and Anastasio, 2005; Zellner et al., 1990):

$\mathrm{HOOH}+h v \rightarrow 2^{\circ} \mathrm{OH}$,

as well as through the photo-Fenton reaction (Arakaki and Faust, 1998),

$\mathrm{Fe}(\mathrm{II})+\mathrm{HOOH} \rightarrow \mathrm{Fe}(\mathrm{III})+{ }^{\circ} \mathrm{OH}+\mathrm{OH}^{-}$

Additional sources of aqueous-phase ${ }^{\circ} \mathrm{OH}$ include photolysis of nitrite and nitrate (Anastasio and McGregor, 2001; Chameides and Davis, 1982; Chu and Anastasio, 2003, 2007; Dubowski et al., 2001; Ervens et al., 2003; Qiu et al., 2002), e.g.:

$\mathrm{NO}_{3}^{-}+h v\left(+\mathrm{H}^{+}\right) \rightarrow^{\cdot} \mathrm{OH}+\mathrm{NO}_{2}$

Published by Copernicus Publications on behalf of the European Geosciences Union. 
The rate of Reaction (R3) is independent of $\mathrm{pH}$ from $\mathrm{pH}$ 1.9 to 8.3 (Anastasio and McGregor, 2001); the proton is included in Reaction (R3) to balance the equation. Hydroxyl radicals react quickly in aqueous drops, with the main sink typically being organic compounds (Arakaki and Faust, 1998; Faust, 1994; Herrmann et al., 2005). This rapid reaction leads to the formation of aqueous alkyl radicals, which then (generally) add oxygen to form organic peroxyl radicals (Ervens et al., 2003; von Sonntag and Schuchmann, 1997). For example, in the case of the ${ }^{\circ} \mathrm{OH}$-initiated reaction with hydrated acetaldehyde, this sequence is (Ervens et al., 2003):

$$
\begin{aligned}
& \cdot \mathrm{OH}+\mathrm{CH}_{3} \mathrm{CH}(\mathrm{OH})_{2} \rightarrow \mathrm{CH}_{3}^{\circ} \mathrm{C}(\mathrm{OH})_{2}+\mathrm{H}_{2} \mathrm{O} \\
& \mathrm{CH}_{3}^{\cdot} \mathrm{C}(\mathrm{OH})_{2}+\mathrm{O}_{2} \rightarrow \mathrm{CH}_{3} \mathrm{C}(\mathrm{OH})_{2} \mathrm{OO}
\end{aligned}
$$

The fate of the resulting organic peroxyl radicals in aqueous phases depends on the type of peroxyl radical (von Sonntag and Schuchmann, 1997). Peroxyl radicals with a hydroxyl group on the peroxyl-bearing carbon (i.e., alpha-hydroxy peroxyl radicals), can undergo fast decomposition to release a more oxidized organic compound and a hydroperoxyl radical (von Sonntag and Schuchmann, 1997). For example, this is the case in the ${ }^{\circ} \mathrm{OH}$-initiated oxidations of aqueous formaldehyde and formic acid, two of the more abundant organic compounds found in tropospheric aqueous phase (Chameides and Davis, 1983; Ervens et al., 2003). In the case of the $\alpha$-hydroxy peroxyl radical derived from acetaldehyde in Reaction (R5) above, decomposition forms $\mathrm{HO}_{2}^{*}$ and acetic acid (Ervens et al., 2003):

$$
\mathrm{CH}_{3} \mathrm{C}(\mathrm{OH})_{2} \mathrm{OO} \rightarrow \mathrm{HO}_{2}^{\cdot}+\mathrm{CH}_{3} \mathrm{COOH}
$$

$\mathrm{HO}_{2}^{*}$, the hydroperoxyl radical, can dissociate to form superoxide and $\mathrm{H}^{+}$(pKa $=4.85$, Bielski et al., 1985):

$\mathrm{HO}_{2}^{\bullet} \leftrightarrow{ }^{\bullet} \mathrm{O}_{2}^{-}+\mathrm{H}^{+}$

Dismutation of $\mathrm{HO}_{2}^{*}$ and ${ }^{\circ} \mathrm{O}_{2}^{-}$can then form hydrogen peroxide (Bielski et al., 1985):

$$
\begin{aligned}
& \mathrm{HO}_{2}^{*}+\mathrm{HO}_{2}^{\cdot} \rightarrow \mathrm{HOOH}+\mathrm{O}_{2} \\
& \mathrm{HO}_{2}^{\cdot}+{ }^{\cdot} \mathrm{O}_{2}^{-}+\mathrm{H}^{+} \rightarrow \mathrm{HOOH}+\mathrm{O}_{2}
\end{aligned}
$$

Peroxyl radicals that do not contain an $\alpha$-hydroxy group follow a variety of bimolecular pathways that can result in the formation of $\mathrm{HOOH}$, alkoxyl radicals, carbonyl compounds, and alcohols (von Sonntag and Schuchmann, 1997). This is illustrated below for a generic organic compound $\mathrm{R}_{2} \mathrm{CH}_{2}$, starting with hydroxyl radical reaction to form peroxyl radicals $\left(\mathrm{R}_{2} \mathrm{CHOO}\right)$ :

$2^{\circ} \mathrm{OH}+2 \mathrm{R}_{2} \mathrm{CH}_{2}\left(+\mathrm{O}_{2}\right) \rightarrow 2 \mathrm{R}_{2} \mathrm{CHOO}^{\bullet}$

The two peroxyl radicals can then combine to form an intermediate tetroxide,

$2 \mathrm{R}_{2} \mathrm{CHOO}^{*} \rightarrow \mathrm{R}_{2} \mathrm{CHOOOOCHR}$,

which can undergo four possible decompositions:
$\mathrm{R}_{2} \mathrm{CHOOOOCHR}{ }_{2} \rightarrow \mathrm{R}_{2} \mathrm{C}=\mathrm{O}+\mathrm{R}_{2} \mathrm{CHOH}+\mathrm{O}_{2}$

$\mathrm{R}_{2} \mathrm{CHOOOOCHR}_{2} \rightarrow 2 \mathrm{R}_{2} \mathrm{C}=\mathrm{O}+\mathrm{HOOH}$

$\mathrm{R}_{2} \mathrm{CHOOOOCHR}_{2} \rightarrow 2 \mathrm{R}_{2} \mathrm{CHO}+\mathrm{O}_{2}$

$$
\mathrm{R}_{2} \mathrm{CHOOOOCHR}_{2} \rightarrow \mathrm{R}_{2} \mathrm{CHOOCHR}_{2}+\mathrm{O}_{2}
$$

The kinetics and product yields from the aqueous reactions of ${ }^{\bullet} \mathrm{OH}$ with a range of organic compounds have been studied using gamma $(\gamma)$ radiation and pulse radiolysis (Christensen and Gustafsson, 1972; Nese et al., 1995; Pan et al., 1993a, b; Piesiak et al., 1984; Schuchmann and von Sonntag, 1984; Schuchmann et al., 1990, 1995; Schuchmann and von Sonntag, 1977, 1979, 1982, 1983, 1988; Schuchmann et al., 1985; Stemmler and von Gunten, 2000; Ulanski et al., 1996; Zegota et al., 1984). Overall $\mathrm{HOOH}$ yields in these experiments (defined as the rate of $\mathrm{HOOH}$ production divided by the rate of ${ }^{\circ} \mathrm{OH}$ production) ranged from 0.02 to 0.57 , with an average yield of 0.38 . However, radiolysis of aqueous solutions also results in primary formation of $\mathrm{HOOH}$ and $\mathrm{HO}_{2}^{*} /{ }^{\circ} \mathrm{O}_{2}^{-}$, so $\mathrm{HOOH}$ yields solely from reaction of ${ }^{\circ} \mathrm{OH}$ with organic will be lower than these overall yields. $\left({ }^{\circ} \mathrm{OH}\right.$ also undergoes self-reaction to form $\mathrm{HOOH}$, but because aqueous concentrations of ${ }^{\circ} \mathrm{OH}$ are extremely low this reaction is not a significant source of $\mathrm{HOOH}$ in aqueous atmospheric phases.) Unimolecular elimination of $\mathrm{HO}_{2}^{*}$ radicals from $\alpha$-hydroxyperoxyl radicals (i.e., Reaction R6) represents a significant pathway for $\mathrm{HOOH}$ production in many of these past experiments. However, the results also suggest that bimolecular reactions (e.g., Reaction R11 followed by Reactions R12-R16) can compete with unimolecular elimination (Schuchmann and von Sonntag, 1984) and that superoxide can cross-terminate with other peroxyl radicals (Pan et al., 1993b). Work by Stemmler and von Gunten (2000) using the reaction of ${ }^{\circ} \mathrm{OH}$ with 2-butoxyethanol found a yield of $\mathrm{HO}_{2}^{*}$ of 0.25 and a yield of $\mathrm{HOOH}$ through pathways other than $\mathrm{HO}_{2}^{\circ}$ of 0.17 , further showing that substantial $\mathrm{HOOH}$ can be produced via mechanisms other than the $\mathrm{HO}_{2}^{*} /{ }^{\circ} \mathrm{O}_{2}^{-}$disproportionation reactions (Reaction R8 and R9). The yield of $\mathrm{HOOH}$ from the ${ }^{\circ} \mathrm{OH}$-mediated oxidation of aqueous organic compounds probably varies considerably, depending on the production rate of ${ }^{\bullet} \mathrm{OH}$, concentrations of ${ }^{\bullet} \mathrm{OH}$ and organic compounds, and other environmental conditions (Stemmler and von Gunten, 2000). But this yield is an important parameter since most aqueous ${ }^{\circ} \mathrm{OH}$ reacts with organic compounds and since $\mathrm{HOOH}$ is an important component of the oxidative capacity of cloud water droplets.

In addition to its role in aqueous reactions in the atmosphere, $\mathrm{HOOH}$ is also an important constituent in snow and ice. In long-term ice, $\mathrm{HOOH}$ has a half-life of approximately 5000 years in Greenland and 15000 years in the Antarctic, and its presence in ice cores gives an indication of historical atmospheric oxidative capacity (Hutterli et al., 2003; Legrand and Mayewski, 1997). In the photic zone of the snowpack, $\mathrm{HOOH}$ photolyzes to ${ }^{\circ} \mathrm{OH}$, which can oxidize 
compounds in the snow and form a variety of volatile species (e.g., $\mathrm{HCHO}$ and $\mathrm{Br}_{2}$ ), which in turn can be emitted from the snow surface to the atmospheric boundary layer (Chu and Anastasio, 2005).

Laboratory experiments indicate that the photolytic lifetime of $\mathrm{HOOH}$ in polar snows during the summer should be on the order of weeks to a few months (Chu and Anastasio, 2005; Jacobi et al., 2006). Yet field measurements show that $\mathrm{HOOH}$ is present throughout the snowpack (Legrand and Mayewski, 1997; Sigg and Neftel, 1991), indicating its net lifetime in polar snow and ice must be long enough to survive burial by new snow until $\mathrm{HOOH}$ is beneath the photic zone. For example, at Summit, Greenland, where the photic zone for $\mathrm{HOOH}$ is approximately $30 \mathrm{~cm}$ (i.e., 2 times the efolding depth, Galbavy et al., 2007) and the snow accumulation rate is approximately $5 \mathrm{~cm} \mathrm{mo}^{-1}$, it would take approximately 5 mo to bury $\mathrm{HOOH}$ in surface snow to below the photic zone. This is much longer than the calculated 24-hraverage lifetime of $\mathrm{HOOH}$ on the summer solstice of $140 \mathrm{hr}$ (Chu and Anastasio, 2005).

There are at least two possible explanations for the discrepancy between laboratory-derived $\mathrm{HOOH}$ lifetimes and those estimated from field observations in snow and ice: (1) $\mathrm{HOOH}$ in natural snow has a longer photolytic lifetime than determined in laboratory ices, and (2) chemical reactions on snow grains might effectively recycle $\mathrm{HOOH}$. This first possibility has been examined in recent work and does not appear to explain the $\mathrm{HOOH}$ lifetime discrepancy (Beine and Anastasio, 2011). The efficacy of the second possibility - i.e., $\mathrm{HOOH}$ recycling-depends on the yields of $\mathrm{HOOH}$ from the reactions of snow grain ${ }^{\circ} \mathrm{OH}$ with organics. In this mechanism, $\mathrm{HOOH}$ in snow or ice is photolyzed to form hydroxyl radicals (Chu and Anastasio, 2005), which then react with organics to form peroxyl radicals, which lead to $\mathrm{HOOH}$. If the yields of $\mathrm{HOOH}$ are high enough, ${ }^{\circ} \mathrm{OH}$ reactions with organics could effectively recycle $\mathrm{HOOH}$ in snow or ice and significantly extend its lifetime. Recycling of $\mathrm{HOOH}$ via - $\mathrm{OH}$ reaction with organics has been proposed to occur in cloud drops (Lelieveld and Crutzen, 1990), and has been proposed as a mechanism to explain hydroperoxide formation in nascent marine aerosols (Zhou et al., 2008), but has not been studied on ice.

This work is motivated by two questions: (1) In atmospheric aqueous phases, how efficiently can the reaction of - $\mathrm{OH}$ with organic compounds form $\mathrm{HOOH}$ ? and (2) In ice and snow, does recycling of $\mathrm{HOOH}$ through reaction of ${ }^{\circ} \mathrm{OH}$ with organic compounds significantly extend the net lifetime of $\mathrm{HOOH}$ ? To answer these questions we have measured the yield of $\mathrm{HOOH}$ from the reaction of $\cdot \mathrm{OH}$ with ten model organic compounds, in both aqueous solution and ice, at various $\mathrm{pH}$ values and temperatures.

\section{Methods}

\subsection{Materials}

Acetonitrile (HPLC grade), ethylenediamine tetraacetic acid (EDTA, molecular biology grade), formaldehyde (as paraformaldehyde, $95 \%$ ), glycine (>99\%), phenylalanine (>98\%), benzoic acid $(99 \%)$, octanol $(99 \%)$, octanal (>99\%), octanoic acid (>99\%), octanedioic acid (>98\%), and horseradish peroxidase (HRP) were from Sigma. Parahydroxyphenylacetic acid (POHPAA) was from TCI. Sulfuric acid (Optima grade), sodium borate (ACS grade), sodium nitrate (ACS grade), sodium formate (ACS grade), potassium hydrogen phthalate (KHP, ACS grade), and hydrogen peroxide (ACS grade) were from Fisher Chemical. Formaldehyde solution $(<1 \%)$ was made from paraformaldehyde by stirring in $60^{\circ} \mathrm{C}$ water for $1 \mathrm{~h}$ (Sigma-Aldrich, 2010). All other chemicals were used as received.

High purity water ("UV Milli-Q water") was water from a Millipore Milli-Q Plus system with an upstream Barnstead International DO813 activated carbon cartridge that was further treated to remove residual organic compounds by adding hydrogen peroxide (to make a $0.5 \mathrm{mM}$ solution) and then illuminating for $24 \mathrm{~h}$ with $254 \mathrm{~nm}$ UV light in a Rayonet RPR200 photoreactor with 4 RPR-2537 bulbs.

\subsection{Solution and ice samples}

To determine the yield of $\mathrm{HOOH}$ from the reaction of ${ }^{\circ} \mathrm{OH}$ with an organic compound, we measured the rate of $\mathrm{HOOH}$ formation during illumination of two parallel solutions: one containing $0.20 \mathrm{mM}$ of model organic compound and one containing $0.20 \mathrm{mM}$ of organic and $0.50 \mathrm{mM}$ nitrate (as the source of $\left.{ }^{\circ} \mathrm{OH}\right)$. At this concentration of organic compound we expect that essentially all of the photoproduced ${ }^{\circ} \mathrm{OH}$ will react with the organic. The $\mathrm{pH}$ in both solutions was identically adjusted by adding sulfuric acid $(\mathrm{pH} \leq 5)$ or sodium borate $(\mathrm{pH}>5)$. Working solutions were made the day of the experiment, and stored in amber glass bottles until use.

Aqueous samples were illuminated in airtight FUV quartz cuvettes $\left(2 \mathrm{~cm}\right.$ path length, $8 \mathrm{~cm}^{3}$ volume, Spectrocell). Ice samples were frozen in either capped air-tight $1 \mathrm{~cm}$ FUV cuvettes (Spectrocell) or $1 \mathrm{ml}$ PTFE beakers (Fisher Scientific). For beaker samples, $0.5 \mathrm{ml}$ aliquots of test solution were placed in each beaker and covered with Parafilm until illumination. For cuvettes, $1 \mathrm{ml}$ of sample was placed in each 3-ml cuvette and capped. Samples were then frozen for $1 \mathrm{~h}$ at $-10^{\circ} \mathrm{C}$ in a custom, Peltier-cooled freeze chamber (Paige Instruments). Cuvettes were frozen horizontally. Each method gave similar results in this investigation, but had different advantages: beakers allowed more time points to be collected (because more beakers than cuvettes could be fit in our illumination system) and had a photon flux approximately two times that of cuvettes, while cuvette samples 
were sealed with caps, preventing exchange of materials between the ice sample and room air.

\subsection{Illumination setup}

Separate, but very similar, solar simulator illumination systems were used for aqueous and ice samples. Aqueous samples were stirred continuously, and maintained at the desired temperature with a recirculating water bath. The light source was a $1000 \mathrm{~W}$ high-pressure xenon-arc source, filtered to approximate sunlight using the method of Faust (1993). The illumination system held up to three cuvettes in series, with a PTFE block behind the last cuvette to reflect light back into the cuvettes. During an experiment, aliquots of illuminated solution were periodically removed to measure the $\mathrm{HOOH}$ concentration. Dark control samples were placed in quartz cuvettes, completely wrapped in foil, and kept in the illumination chamber away from the light path.

For ice samples, the simulated sunlight illumination system generally followed the method of Ram and Anastasio (2009). However, instead of diffusing the light with a PTFE sheet, a 3-mm thick quartz (GE 021) plate, roughly ground on both sides, was used. Beakers containing ice samples sat directly on a Peltier-cooled copper plate. A thermocouple probe was inserted into one control beaker filled with $0.5 \mathrm{ml}$ of UV Milli-Q water for temperature monitoring and to maintain sample temperatures at $-5^{\circ} \mathrm{C}$. The plate measured $100 \mathrm{~cm} \times 100 \mathrm{~cm}$, allowing 49 beaker positions in a $7 \times 7$ grid; samples were placed clustered around the area of highest illumination at the center. Dark samples were placed toward the edges of the illumination area, and covered with foil to prevent light exposure. One polished quartz plate, covering the entire illumination area, was placed over all beakers to reduce air exchange. Dry air was blown across the top of this plate to prevent condensation. Cuvettes containing ice samples were placed on the same cooled plate used for beaker illuminations, with 2 rows of 7 cuvettes each. Dark samples were placed at the edges of the plate and covered with foil. The quartz cover plate and dry air were used as described above for beaker illuminations.

\subsection{Actinometry}

2-nitrobenzaldehyde (2NB) was used as a chemical actinometer to measure the photon flux in each illumination system on the day of each experiment, following the method of Ram and Anastasio (2009). As described recently (Galbavy et al., 2010), 2NB is a robust actinometer whose rate constant for photodecay is independent of phase (liquid or ice), temperature, and illumination wavelength. For aqueous samples, the rate constant for $2 \mathrm{NB}$ photodegradation $(j(2 \mathrm{NB}))$ was measured daily for each of the cuvette positions. For ice samples, daily measurement of every illumination position was impractical, so we measured $j(2 \mathrm{NB})$ in a central, reference position each day and determined values at other po- sitions using previously determined correction factors (Ram and Anastasio, 2009). To determine these correction factors we measured $j(2 \mathrm{NB})$ at every beaker or cuvette position several times over the course of this study; the resulting correction factor $\left(F_{2 \mathrm{NB}, x}\right)$ for each beaker or cuvette position $(x)$ relative to the position of maximum intensity (the reference position, "ref") was calculated as:

$F_{2 \mathrm{NB}, x}=\frac{j(2 \mathrm{NB}), x}{j(2 \mathrm{NB}), \mathrm{ref}}$

Values of $F_{2 \mathrm{NB}, x}$ ranged from 0.71 to 1 , i.e., photon flux corrections were relatively minor. During ice illumination, one sample was removed at each illumination time point and analyzed for $\mathrm{HOOH}$. The amount of $\mathrm{HOOH}$ produced in each ice sample at a given position was corrected for differences in photon flux using:

$[\mathrm{HOOH}]_{\text {corrected }}=[\mathrm{HOOH}]_{0}+\frac{[\mathrm{HOOH}]_{x}-[\mathrm{HOOH}]_{0}}{F_{2 \mathrm{NB}, x}}$

where $[\mathrm{HOOH}]_{0}$ is the $\mathrm{HOOH}$ concentration at time zero and $[\mathrm{HOOH}]_{x}$ is the measured concentration in the sample at position $x$ (at some time $t$ ).

Typical $j(2 \mathrm{NB})$ values for our simulated sunlight illuminations were $0.019 \mathrm{~s}^{-1}$ for aqueous solutions and $0.017 \mathrm{~s}^{-1}$ for ice samples. These are similar to ambient values; for example, $j\left(2 \mathrm{NB}\right.$ ) was calculated as $0.018 \mathrm{~s}^{-1}$ at the snow surface at Summit, Greenland, on midday on 5 August, 2005 (Galbavy et al., 2010), and measured as $0.013 \mathrm{~s}^{-1}$ above a bare field at midday on the summer solstice in Davis, CA (Anastasio and McGregor, 2001).

\subsection{Calculation of $\mathrm{HOOH}$ yield}

We define the $\mathrm{HOOH}$ yield as the ratio of the rate of $\mathrm{HOOH}$ formation to the rate of ${ }^{\circ} \mathrm{OH}$ production:

Yield $=\frac{R(\mathrm{HOOH})}{R(\mathrm{OH})}=\frac{R(\mathrm{HOOH}) / j(2 \mathrm{NB})}{R(\mathrm{OH}) / j(2 \mathrm{NB})}$

where $R(\mathrm{HOOH})$ is the measured rate of production of hydrogen peroxide (Sect. 2.6) and $R(\mathrm{OH})$ is the calculated rate of production of hydroxyl radical from nitrate photolysis (Sect. 2.7), both normalized to $j(2 \mathrm{NB})$. Because two molecules of ${ }^{\bullet} \mathrm{OH}$ are required to produce one molecule of HOOH (e.g., Reactions R3, R10, R11, R13), complete conversion of ${ }^{\cdot} \mathrm{OH}$ to $\mathrm{HOOH}$ via reaction with organics should give a yield of 0.5 , i.e., this is the expected upper bound. Uncertainty in the yield was expressed by propagating the standard errors of $R(\mathrm{HOOH})$ and $R(\mathrm{OH})$.

\subsection{Measurement of $\mathrm{HOOH}$ concentration, $R(\mathrm{HOOH})$, and $R(\mathrm{HOOH}) / j(2 \mathrm{NB})$}

Hydrogen peroxide concentrations were determined with the HPLC post-column derivatization fluorescence method of Kok et al. (1995), using instrumentation previously described 
in Chu and Anastasio (2005): only PEEK or Teflon components were used between the sample injector and the detector. A standard curve for hydrogen peroxide in UV Milli-Q water was run each day. Illuminated samples were removed and analyzed for $\mathrm{HOOH}$ at known illumination times up to $6 \mathrm{~h}$. Ice samples were thawed in the dark at room temperature immediately before analysis.

The rate of $\mathrm{HOOH}$ formation, $R(\mathrm{HOOH})$, for each illuminated sample pair (i.e., with and without nitrate) was determined by performing a linear regression on the data points of $[\mathrm{HOOH}]_{\text {corrected }}$ versus illumination time. Dark (not illuminated) samples were run with each experiment. Of the 160 experiments we performed (both with and without nitrate), only $14 \%$ had dark control $\mathrm{HOOH}$ production rates that were statistically greater than zero ( $95 \%$ confidence limit). Of these, the median ratio of dark control to illuminated production rates was 0.15 . We performed an evaluation of $\mathrm{HOOH}$ production rates and yields both with and without a correction for statistically significant darks, and found no meaningful difference in the results. Because of the small number of dark controls showing non-zero $\mathrm{HOOH}$ production, the small magnitude of $\mathrm{HOOH}$ production in dark samples relative to illuminated samples, and the insignificant impact of applying a dark correction, we did not include a correction for dark samples in our $R(\mathrm{HOOH})$ values.

Values of $R(\mathrm{HOOH})$ for each sample pair (with and without nitrate) were divided by the measured $j(2 \mathrm{NB}$ ) value for each sample to correct for any difference in light flux. To subtract any background production from direct photoreaction of the organic compound, $R(\mathrm{HOOH}) / j(2 \mathrm{NB})$ for the sample without nitrate was subtracted from the value of $R(\mathrm{HOOH}) / j(2 \mathrm{NB})$ determined for the sample with nitrate. Listed uncertainties in values of the net $R(\mathrm{HOOH}) / j(2 \mathrm{NB})$ are \pm 1 standard error, determined from the SE of the slope of $[\mathrm{HOOH}]_{\text {corrected }}$ versus illumination time and including propagated errors from $j(2 \mathrm{NB})$.

\subsection{Calculation of $R(\mathrm{OH})$}

We used $0.50 \mathrm{mM}$ nitrate as a photochemical source of hydroxyl radical (Reaction R3, Chu and Anastasio, 2003). In order to calculate the rate of ${ }^{\circ} \mathrm{OH}$ formation in each sample, we first measured the rate constant for ${ }^{\circ} \mathrm{OH}$ formation from nitrate photolysis, $j\left(\mathrm{NO}_{3}^{-} \rightarrow{ }^{\bullet} \mathrm{OH}\right)$, in our illumination systems using $\mathrm{pH} 5$ solutions containing $0.20 \mathrm{mM}$ sodium benzoate and illuminated at $5{ }^{\circ} \mathrm{C}$. Hydroxyl radical was trapped using sodium benzoate to form para-hydroxybenzoic acid ( $p$-HBA), which was quantified by HPLC and converted to an ${ }^{\circ} \mathrm{OH}$ equivalent using a $p$-HBA yield of $19 \%$ (Chu and Anastasio, 2007). $j(2 \mathrm{NB})$ was measured in the same system on the same day. The average $( \pm 1 \sigma)$ measured ratio, i.e., $\left(j\left(\mathrm{NO}_{3}^{-} \rightarrow^{\cdot} \mathrm{OH}\right) / j(2 \mathrm{NB})\right)_{\text {ref }}$, in our systems was $(1.8 \pm 0.39) \times 10^{-5} \mathrm{~s}^{-1} / \mathrm{s}^{-1}(n=6)$; there was no difference in this value between the two illumination systems. This ratio was adjusted to values at other temperatures using the tem- perature dependence of the quantum yield for ${ }^{\circ} \mathrm{OH}$ formation from nitrate photolysis (Chu and Anastasio, 2003):

$\ln \left(\sigma_{\mathrm{OH}}\right)=(-2400 \pm 480) \frac{1}{T}+(3.6 \pm 0.8)$

Using the value of $\left(j\left(\mathrm{NO}_{3} \rightarrow \cdot \mathrm{OH}\right) / j(2 \mathrm{NB})\right)_{\text {ref }}$, we calculated the $j(2 \mathrm{NB})$-normalized rate of production of ${ }^{\circ} \mathrm{OH}$ in a given illuminated solution with nitrate using:

$\frac{R(\mathrm{OH})}{j(2 \mathrm{NB})}=\left[\mathrm{NO}_{3}^{-}\right] x\left(\frac{j\left(\mathrm{NO}_{3}^{-} \rightarrow \mathrm{OH}\right)}{j(2 \mathrm{NB})}\right)$

where $j(2 \mathrm{NB})$ is the value measured on that day, and $\left[\mathrm{NO}_{3}^{-}\right]$ is the nitrate concentration $(0.50 \mathrm{mM})$.

\section{Results and discussion}

\subsection{Model organic compounds}

A tremendous variety of anthropogenic and biogenic organic species have been detected in atmospheric aqueous phases, snow, and ice, although only a small fraction of the individual molecules have been identified (Altieri et al., 2009; Collett et al., 2008; Desideri et al., 1994; Fries et al., 2008; Grannas et al., 2006; Grannas et al., 2004; Grollert and Puxbaum, 2000; Hutterli et al., 2004; Laniewski et al., 1998; Legrand and Deangelis, 1995; Mazzoleni et al., 2010; Satsumabayashi et al., 2001). For this study, we selected ten model organic compounds (Table 1) to span a wide range of organic functional groups that have either been found, or could reasonably be expected to exist, in snow and atmospheric water drops. Of the compounds we chose, formaldehyde and formate are two of the most abundant organic compounds in natural snow and ice, as well as in atmospheric aqueous phases (Barrie et al., 1992; Dibb and Arsenault, 2002; Finlayson-Pitts and Pitts, 2000; Hutterli et al., 2004; Perrier et al., 2002). Glycine was chosen because it is the simplest amino acid, phenylalanine because it is the simplest aromatic amino acid. Both have been found in atmospheric aerosols and fog waters (Zhang and Anastasio, 2001, 2003), and undoubtedly exist in snow. In addition to phenylalanine, we studied one other aromatic compound - benzoic acid - which has been found in snow (Satsumabayashi et al., 2001). Four of our model compounds contain an 8-carbon chain, but with different terminal functional groups: octanol, octanal, octanoic acid, and octanedioic acid (also known as suberic acid). Finally, we also included 2-butoxyethanol, a widely used, highly soluble, glycol ether that has been studied previously for $\mathrm{HOOH}$ yield (Stemmler and von Gunten, 2000).

\subsection{Typical experiment - illumination of formaldehyde}

Figure 1 shows kinetic results for a typical aqueous experiment, conducted here with formaldehyde. Formaldehyde in aqueous solution undergoes hydration and is primarily present as the gem-diol form, $\mathrm{CH}_{2}(\mathrm{OH})_{2}$; the ratio of 
Table 1. Physical and chemical properties of model organic compounds.

\begin{tabular}{|c|c|c|c|c|c|}
\hline Chemical & Structure & Formula & $\begin{array}{r}\text { Molecular weight } \\
\qquad\left(\mathrm{g} \mathrm{mol}^{-1}\right)\end{array}$ & $\begin{array}{l}\text { Water solubility } \\
\left(\mathrm{mol} \mathrm{L}^{-1}\right)^{*}\end{array}$ & $\mathrm{pKa} *$ \\
\hline Formaldehyde & & $\mathrm{HCHO}$ & 30.0 & 13.3 & na \\
\hline Formate & & $\mathrm{HCOOH}$ & 45.0 & 22.2 & 3.8 \\
\hline Glycine & & $\mathrm{NH}_{2} \mathrm{CH}_{2} \mathrm{COOH}$ & 75.1 & 3.32 & $2.4,9.8$ \\
\hline Phenylalanine & & $\mathrm{HO}_{2} \mathrm{CCH}\left(\mathrm{NH}_{2}\right) \mathrm{CH}_{2} \mathrm{C}_{6} \mathrm{H}_{5}$ & 165.2 & 0.121 & $2.2,9.3$ \\
\hline Benzoic Acid & & $\mathrm{C}_{6} \mathrm{H}_{5} \mathrm{COOH}$ & 122.1 & 0.0278 & 4.2 \\
\hline Octanol & & $\mathrm{CH}_{3}\left(\mathrm{CH}_{2}\right)_{7} \mathrm{OH}$ & 130.2 & 0.00415 & na \\
\hline Octanal & & $\mathrm{CH}_{3}\left(\mathrm{CH}_{2}\right)_{6} \mathrm{CHO}$ & 128.2 & 0.00437 & na \\
\hline Octanoic acid & & $\mathrm{CH}_{3}\left(\mathrm{CH}_{2}\right)_{6} \mathrm{COOH}$ & 144.2 & 0.00548 & 4.9 \\
\hline Octanedioic acid & & $\mathrm{C}_{6} \mathrm{H}_{12}(\mathrm{COOH})_{2}$ & 174.2 & 0.0689 & 4.5 \\
\hline 2-Butoxyethanol & & $\mathrm{CH}_{3}\left(\mathrm{CH}_{2}\right)_{3} \mathrm{O}\left(\mathrm{CH}_{2}\right)_{2} \mathrm{OH}$ & 118.2 & 8.46 & na \\
\hline
\end{tabular}

* Howard and Meylan (1997).

$\mathrm{CH}_{2}(\mathrm{OH})_{2}$ to $\mathrm{HCHO}$ in water at room temperature is $2000: 1$ (Bell et al., 1956). The squares and dotted line show the production of $\mathrm{HOOH}$ by formaldehyde when illuminated (in the absence of nitrate), while the circles and solid line show production of $\mathrm{HOOH}$ in the presence of nitrate during illumination. Adding nitrate (as a photochemical source of ${ }^{\bullet} \mathrm{OH}$ ) to the formaldehyde solution causes the rate of $\mathrm{HOOH}$ production to approximately double. To calculate the net $\mathrm{HOOH}$ production rates and $\mathrm{HOOH}$ yields for each model compound (discussed below), we subtract the production of $\mathrm{HOOH}$ in the absence of nitrate from the production in the presence of nitrate to account for any $\mathrm{HOOH}$ produced by direct reaction of the model compound (Sect. 2.6).

\section{3 $\mathrm{HOOH}$ production rates in solution at $\mathrm{pH} 5$}

Figure 2 shows a comparison of $\mathrm{HOOH}$ production rates, normalized by $j(2 \mathrm{NB})$, with and without nitrate for nine model organic compounds and UV Milli-Q at $\mathrm{pH} 5$ and $5^{\circ} \mathrm{C}$. Without nitrate (open circles), all but one (formate) of the model organic compounds have $\mathrm{HOOH}$ production rates that are indistinguishable from that of UV Milli-Q water at a $95 \%$ confidence interval, so $\mathrm{HOOH}$ production rates for these solutions are probably attributable to background material in the water, and not to photoreaction of the model compound. In contrast, $\mathrm{HOOH}$ does appear to be produced from illumination of formate solution without nitrate: the $95 \%$ lower confidence limit (LCL) for $\mathrm{HOOH}$ production from formate without nitrate $\left(0.80 \mathrm{nM} \mathrm{s}^{-1} / \mathrm{s}^{-1}\right)$, is slightly higher than the $95 \%$ upper confidence limit (UCL) for $\mathrm{HOOH}$ production by UV Milli-Q water $\left(0.64 \mathrm{nM} \mathrm{s}^{-1} / \mathrm{s}^{-1}\right)$.

The solid circles in Fig. 2 show the $j(2 \mathrm{NB})$-normalized $\mathrm{HOOH}$ production rates for solutions with nitrate. Production rates of $\mathrm{HOOH}$ in UV Milli-Q water with and without nitrate are not statistically different $(95 \%$ confidence interval). Glycine also shows similar production rates with and without nitrate, indicating that ${ }^{\circ} \mathrm{OH}$ reaction with glycine does not form appreciable amounts of $\mathrm{HOOH}$. While the rate constant for reaction of ${ }^{\cdot} \mathrm{OH}$ with glycine is modest $(k=$ $8.9 \times 10^{6} \mathrm{M}^{-1} \mathrm{~s}^{-1}$ ), the reaction products include alkyl, carboxy, and aminyl radicals, which should be capable of reacting with molecular oxygen to form organic peroxyl radicals (Stefanic et al., 2001). So the lack of $\mathrm{HOOH}$ production by glycine remains unexplained. The other model compounds, however, do have statistically significant $(95 \%$ confidence level) $\mathrm{HOOH}$ production rates in the presence of nitrate, indicating $\mathrm{HOOH}$ is produced following ${ }^{\circ} \mathrm{OH}$ attack on the compound. $j(2 \mathrm{NB})$-normalized production rates without nitrate 


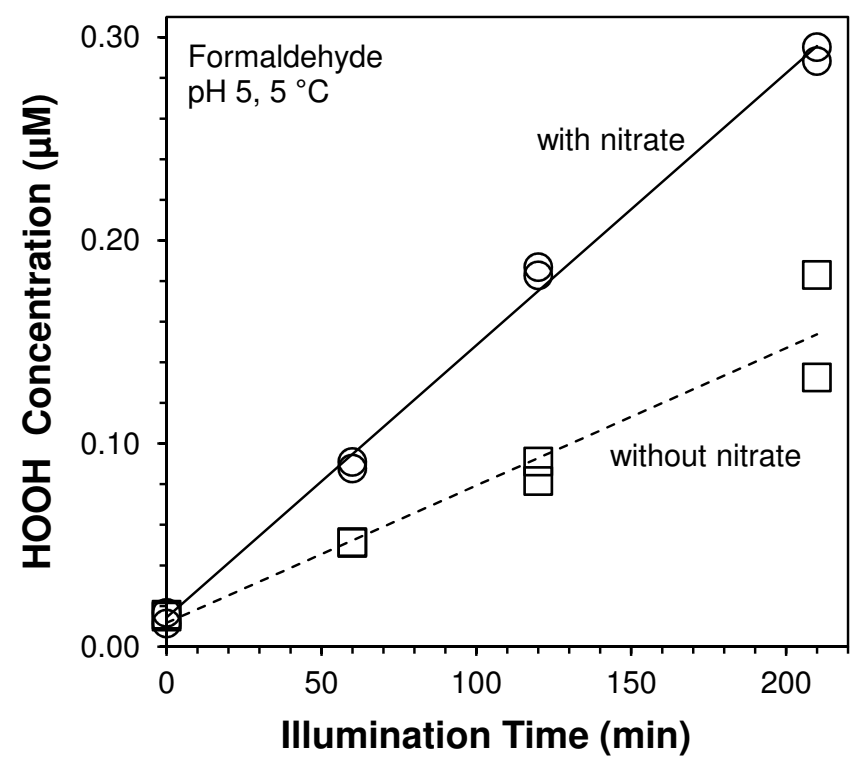

Fig. 1. Production of hydrogen peroxide in illuminated solutions ( $\mathrm{pH} 5,5^{\circ} \mathrm{C}$ ) containing $200 \mu \mathrm{M}$ formaldehyde and either no nitrate (squares) or $500 \mu \mathrm{M}$ nitrate (circles). Rates of $\mathrm{HOOH}$ formation, correlation coefficients $\left(R^{2}\right)$, and $j(2 \mathrm{NB})$ values for these two solutions are $0.68 \mathrm{nM} \mathrm{min}^{-1}, 0.938$, and $0.014 \mathrm{~s}^{-1}$, and $1.3 \mathrm{nM} \mathrm{min}^{-1}$, 0.996 , and $0.014 \mathrm{~s}^{-1}$, respectively.

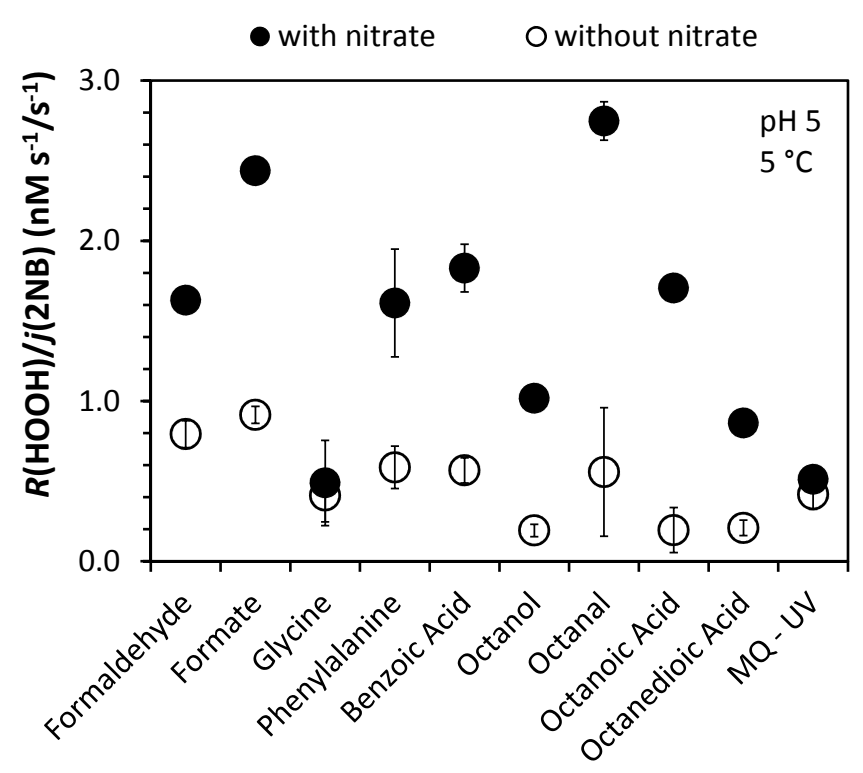

Fig. 2. Production of hydrogen peroxide normalized to measured $j(2 \mathrm{NB})$ in illuminated solutions $\left(\mathrm{pH} 5,5^{\circ} \mathrm{C}\right.$ ) containing $200 \mu \mathrm{M}$ model organic compound and either no nitrate (open circles) or $500 \mu \mathrm{M}$ nitrate (closed circles). UV Milli-Q water did not contain a model compound. Error bars $( \pm 1 \mathrm{SE})$ are the absolute error (net indeterminate error), calculated based on the propagated errors from $R(\mathrm{HOOH})$ and $j(2 \mathrm{NB})$. Some points are average values from several experiments with the same compound.

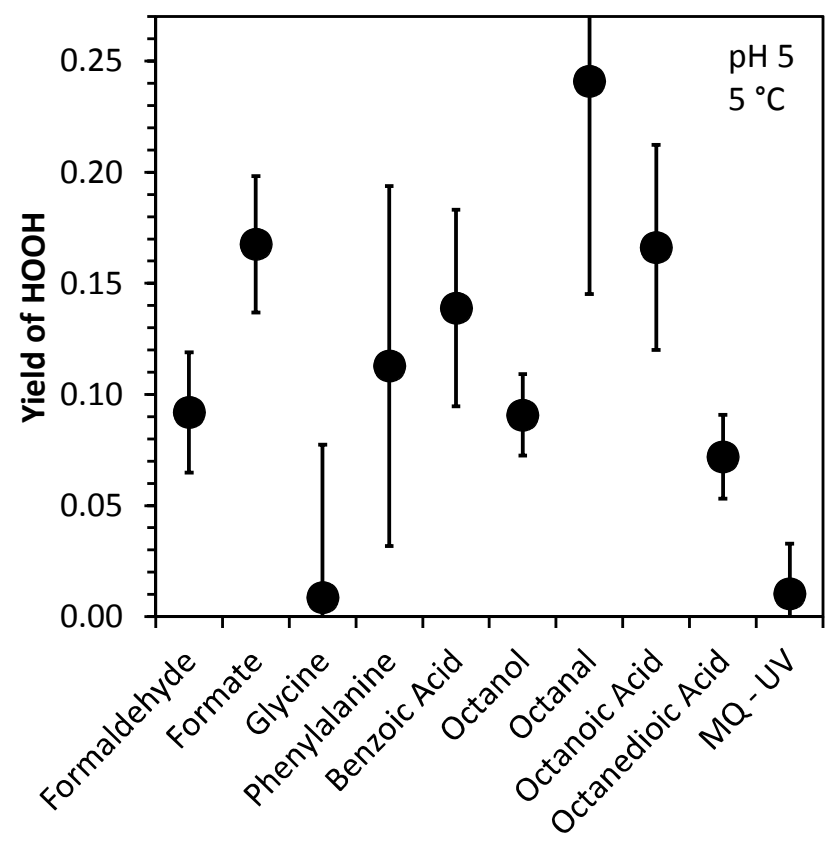

Fig. 3. Yield of hydrogen peroxide from the reaction of ${ }^{\bullet} \mathrm{OH}$ with each model organic compound $\left(\mathrm{pH} 5,5^{\circ} \mathrm{C}\right)$. Error bars $( \pm 1 \mathrm{SE})$ are the absolute error (net indeterminate error), calculated based on the propagated errors from $R(\mathrm{HOOH}), j(2 \mathrm{NB})$, and $R(\mathrm{OH})$.

ranged from $0.19 \mathrm{nM} \mathrm{s}^{-1} / \mathrm{s}^{-1}$ (octanol) to $0.91 \mathrm{nM} \mathrm{s}^{-1} / \mathrm{s}^{-1}$ (formate), with an average of $0.49 \pm 0.20 \mathrm{nM} \mathrm{s}^{-1} / \mathrm{s}^{-1}$ (95\% confidence). With nitrate, $\mathrm{HOOH}$ production rates were $0.49 \mathrm{nM} \mathrm{s}^{-1} / \mathrm{s}^{-1}$ (glycine) to $2.8 \mathrm{nM} \mathrm{s}^{-1} / \mathrm{s}^{-1}$ (octanal), with an average of $1.6 \pm 0.55 \mathrm{nM} \mathrm{s}^{-1} / \mathrm{s}^{-1}$ ( $95 \%$ confidence). The average ratio of the $\mathrm{HOOH}$ production rate with nitrate to that without nitrate was 4.6 , and ranged between 1.2 (glycine) to 10.8 (2-butoxyethanol).

Figure 3 shows the $\mathrm{HOOH}$ yields from ${ }^{\circ} \mathrm{OH}$ reaction with the model compounds at $\mathrm{pH} 5\left(5^{\circ} \mathrm{C}\right)$; as described in section 2.6 , our yield describes the number of molecules of $\mathrm{HOOH}$ formed for every reaction of ${ }^{\circ} \mathrm{OH}$ with organic compound. As could be expected, compounds with higher rates of production of $\mathrm{HOOH}$ (Fig. 2) generally have higher yields. $\mathrm{HOOH}$ yields for the model organic compounds at $\mathrm{pH} 5\left(5^{\circ} \mathrm{C}\right)$ range from essentially zero (glycine) to 0.24 (octanal), with an average of $0.12 \pm 0.05$ ( $95 \%$ confidence interval) and a median of 0.11. Error bars in Fig. 3 show the net indeterminate error for each value expressed as $\pm 1 \mathrm{SE}$; therefore, the error bars represent the likely range of true values for each measurement, and are larger than just precision measurements based on repeated experimental measurements of each value. The average relative standard error for the $\mathrm{HOOH}$ yield for our compounds (excluding glycine) was $34 \%$.

Examining the $\mathrm{HOOH}$ yields in Fig. 3 indicates that the number of carbons on the organic compound does not predict yield, as single-carbon compounds (formaldehyde and formate) have yields in the same range as the 8-carbon 
compounds. Indeed, $\mathrm{HOOH}$ yields for most of the compounds fall within a relatively small range, regardless of compound size or class. For three of the 8-carbon compounds (octanal, octanoic acid, and octanedioic acid) increasing the degree of oxidation decreases the $\mathrm{HOOH}$ yield, but this does not hold true for octanol, which is the least oxidized and has a low yield of $\mathrm{HOOH}$. Both phenylalanine and benzoic acid contain aromatic rings, but this does not appear to influence $\mathrm{HOOH}$ production, as their $\mathrm{HOOH}$ yields are not noticeably different than those of the other model compounds. Glycine, the simplest amino acid, is the only compound without any appreciable production of $\mathrm{HOOH}$ following reaction with ${ }^{\circ} \mathrm{OH}$.

\section{$3.4 \mathrm{pH}$ dependence of $\mathrm{HOOH}$ production rates and yields in solution}

Figure $4 \mathrm{a}$ and $\mathrm{b}$ show the $\mathrm{pH}$ dependence of the $j(2 \mathrm{NB})$ normalized rates of $\mathrm{HOOH}$ production with and without nitrate, respectively. Results for UV Milli-Q are shown with blue diamonds; error bars (shown only for UV Milli-Q) are the $95 \%$ confidence interval around each measurement. With nitrate (Fig. 4a), most model compounds show $\mathrm{HOOH}$ production rates significantly greater than UV Milli-Q water: at $\mathrm{pH} 2$, all model compounds show production statistically greater than UV Milli-Q, while at $\mathrm{pH} 5$ and 7, respectively, all but one (glycine) and two (formaldehyde and benzoic acid) compounds do so. As shown in Fig. 4a, all compounds show a $\mathrm{pH}$ dependence in solutions with nitrate, with increased $\mathrm{HOOH}$ production at lower $\mathrm{pH}$ values. Octanal has the highest production rate at $\mathrm{pH} 2$, approximately 2.5 times as high as the lowest producer, glycine. Octanal also has the highest production rate at $\mathrm{pH} \mathrm{7,} \mathrm{approximately} \mathrm{three} \mathrm{times}$ higher than most other model compounds. For all model organics tested, the average $j(2 \mathrm{NB})$-normalized production rate of $\mathrm{HOOH}( \pm 95 \%$ confidence limit) was $3.1 \pm 0.33$, $1.7 \pm 0.26$, and $1.3 \pm 0.36 \mathrm{nM} \mathrm{s}^{-1} / \mathrm{s}^{-1}$ at $\mathrm{pH} 2,5$, and 7 respectively.

In the absence of nitrate, illumination of most model compounds gives $\mathrm{HOOH}$ production rates that are indistinguishable from UV Milli-Q water (Fig. 4b). At pH 2, formate and octanal have production greater than UV Milli-Q water at the $95 \%$ confidence level; at $\mathrm{pH} 5$, only formate does. At higher $\mathrm{pH}$ values, model compounds generally show $\mathrm{HOOH}$ production rates similar to UV Milli-Q water, indicating that direct photoreactions of the compounds to produce $\mathrm{HOOH}$ are insignificant at higher $\mathrm{pH}$ values.

Figure 5 shows the $\mathrm{HOOH}$ yields for aqueous solutions of model compounds at $\mathrm{pH}$ values ranging from 2.0 to 8.5. Similar to the $\mathrm{HOOH}$ production in the presence of nitrate (Fig. 4a), the $\mathrm{HOOH}$ yields also depend on $\mathrm{pH}$, with higher yields at lower $\mathrm{pH}$. Octanal shows the largest yield for of any of the model compounds, with a maximum of 0.35 at $\mathrm{pH}$ 2.0. Glycine, with a yield nearly zero at $\mathrm{pH} 5$, has a yield (0.17) much closer to other compounds at $\mathrm{pH} 2$. The ob-
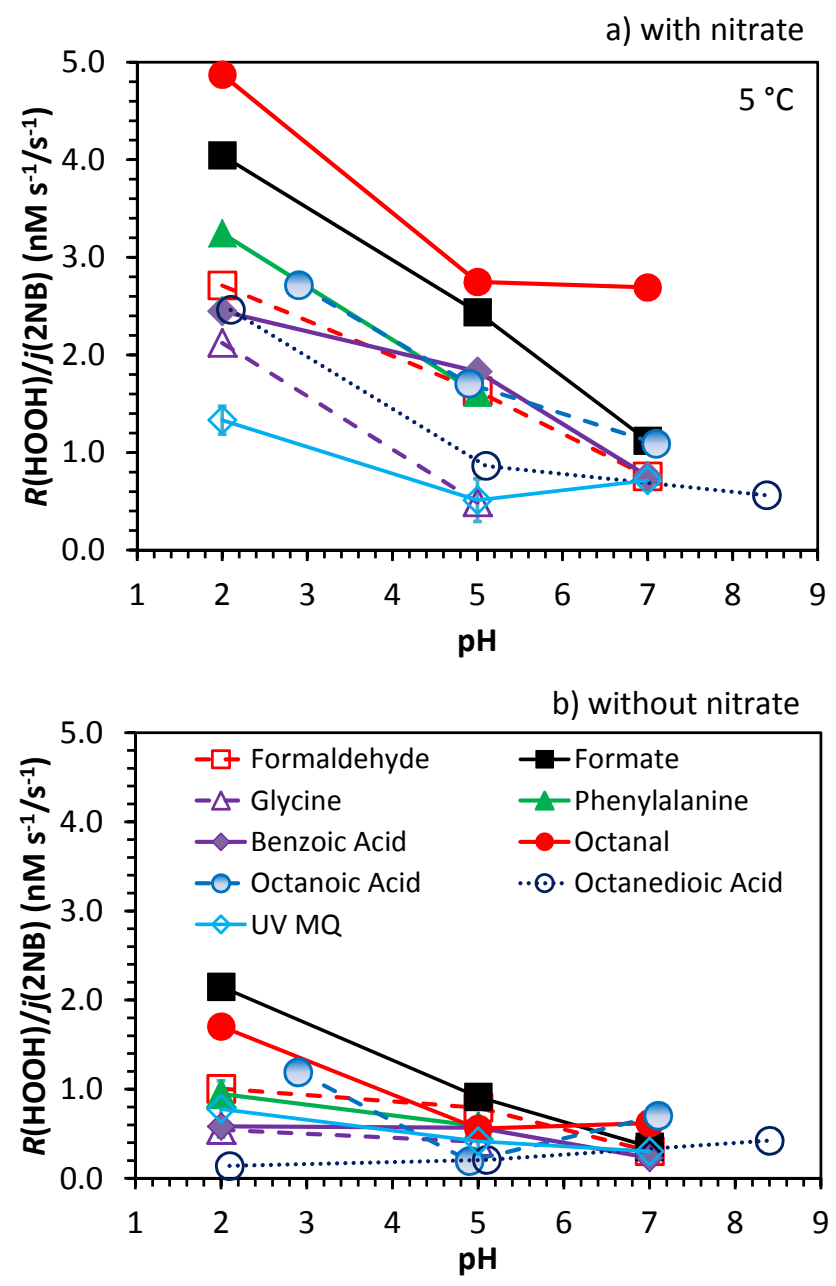

Fig. 4. $\mathrm{pH}$ dependence of hydrogen peroxide production $\left(5^{\circ} \mathrm{C}\right.$, normalized by $j(2 \mathrm{NB})$ ) for illuminated solutions containing: a) model compound $(200 \mu \mathrm{M})$ and nitrate $(500 \mu \mathrm{M})$, and b) model compound only. UV Milli-Q water did not contain a model compound. Error bars (blue) are the $95 \%$ confidence interval of UV Milli-Q water result.

served $\mathrm{pH}$ dependence of $\mathrm{HOOH}$ yield does not appear to be related to acid-base differences in the organic molecules; for example, three of the model compounds (formaldehyde, octanal, and octanal) will have the same molecular form at all $\mathrm{pH}$ values tested. Glycine and phenylalanine contain amino nitrogens that are protonated (i.e., as $\mathrm{RNH}_{3}^{+}$) at all $\mathrm{pH}$ values we tested. Based on their pKa values (Table 1), carboxylic acids on these two amino acids-as well as on four of the other model organic compounds (benzoic acid, octanoic acid, octanedioic acid, and formate)-will be primarily protonated (i.e., $\mathrm{RC}(\mathrm{O}) \mathrm{OH}$ ) at $\mathrm{pH} 2$ and primarily deprotonated (i.e., $\mathrm{RC}(\mathrm{O}) \mathrm{O}^{-}$) at $\mathrm{pH} 5$ and above. The pKa for the carboxylic acid of glycine is 2.4 (Table 1), thus at $\mathrm{pH} 2$, $40 \%$ of the carboxylic acid group is deprotonated, while it is essentially completely deprotonated at $\mathrm{pH}$. While this 


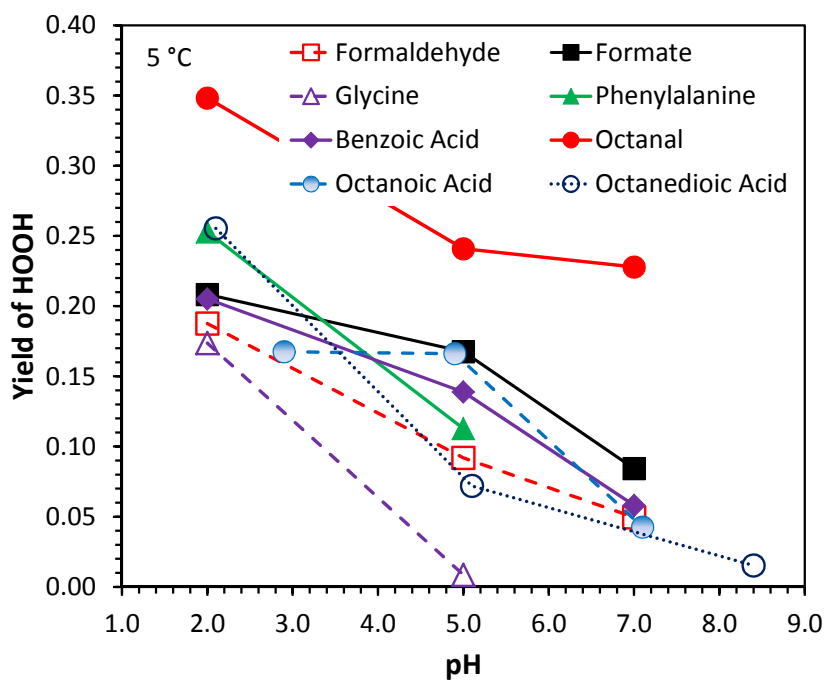

Fig. 5. $\mathrm{pH}$ dependence of the $\mathrm{HOOH}$ yield from reaction of ${ }^{\bullet} \mathrm{OH}$ with each model compound at $5^{\circ} \mathrm{C}$.

protonation state of the carboxylic acid group might be related to the $\mathrm{pH}$ dependence of the $\mathrm{HOOH}$ yield of glycine, phenylalanine has a similar pKa value of 2.2, but it shows significant $\mathrm{HOOH}$ production at $\mathrm{pH}$ 5. Despite the differences in acid-base speciation, all of the model organic compounds have $\mathrm{pH}$-dependent yields of $\mathrm{HOOH}$.

The $\mathrm{HOOH}$ yield for octanal remains noticeably higher than the yields for the other model organic compounds at all $\mathrm{pH}$ values tested. With the exceptions of octanal, and of glycine at $\mathrm{pH} 5$, all other compounds have similar yields at a given $\mathrm{pH}$, and show a similar decrease in $\mathrm{HOOH}$ yield as $\mathrm{pH}$ increases. The high yield for octanal resists ready explanation, but might be related to the aldehyde group. For example, while the other 8-carbon compounds show lower yields, there is no other compound that is predominantly an aldehyde in solution since formaldehyde in solution is present mainly in the gem-diol form, $\mathrm{CH}_{2}(\mathrm{OH})_{2}$. In contrast, the aldehyde group in octanal does not hydrate to a significant degree (Zhao et al., 2005).

It is unclear to us why the $\mathrm{HOOH}$ yields depend on $\mathrm{pH}$. This effect is not due to differences in ${ }^{\circ} \mathrm{OH}$ production from nitrate photolysis, which is independent of $\mathrm{pH}$ between at least pH 2 and 8 (Anastasio and McGregor, 2001). Reaction (R8), the disproportionation of hydroperoxyl/superoxide radicals to form $\mathrm{HOOH}$, is $\mathrm{pH}$ dependent, with a maximum reaction rate constant at $\mathrm{pH} 4.8$ (Bielski et al., 1985). However, if this reaction were the rate-limiting step, $\mathrm{HOOH}$ production should be higher at $\mathrm{pH} 5$ and lower at $\mathrm{pH} 2$, which is the opposite of the pattern seen in our data (Fig. 4a). Stemmler and von Gunten (2000) found that bimolecular decay reactions of peroxyl radicals (corresponding to our Recation R12-R14) were not $\mathrm{pH}$ dependent, and that the $\mathrm{HOOH}$ yield was not different between $\mathrm{pH} 3$ and $\mathrm{pH} 6$. These re- sults suggest our $\mathrm{pH}$-dependent yields are not caused by $\mathrm{pH}$ dependence in the reactions of the tetroxide intermediates. Another possibility is that the fates of $\mathrm{HO}_{2}^{*}$ and ${ }^{\circ} \mathrm{O}_{2}^{-}$in solution might be different. For example, Lelieveld and Crutzen (1991) found a tripling of aqueous $\mathrm{HOOH}$ concentrations in a modeled cloud with a $\mathrm{pH}$ change from 6 to 4 , because while ozone is not a sink for $\mathrm{HO}_{2}^{*}$ (at $\left.\mathrm{pH} 4\right)$, it is a sink for superoxide (at pH 6):

$\mathrm{O}_{3}+\mathrm{O}_{2}^{-}+\mathrm{H}_{2} \mathrm{O} \rightarrow \cdot \cdot \mathrm{OH}+\mathrm{OH}^{-}+2 \mathrm{O}_{2}$

This reaction would deplete superoxide and thereby reduce $\mathrm{HOOH}$ production via hydroperoxyl/superoxide disproportionation (Reaction R8 and R9) at higher $\mathrm{pH}$ values. Ozone formed from the minor channel of nitrate photolysis (Warneck and Wurzinger, 1988) in our solutions might be responsible for such superoxide depletion.

Another possible reason for the observed $\mathrm{pH}$ dependence in our $\mathrm{HOOH}$ production rates and yields is metal contamination, e.g., from the sulfuric acid that we used to adjust $\mathrm{pH}$. While we used high quality (Optima grade) $\mathrm{H}_{2} \mathrm{SO}_{4}$, it certainly contains some metals, including iron and copper, which are redox-active metals that can enhance $\mathrm{HOOH}$ production from $\mathrm{HO}_{2}^{-}$and ${ }^{\circ} \mathrm{O}_{2}^{-}$(Deguillaume et al., 2004). However, one argument against this hypothesis is that the $\mathrm{pH} 2$ solutions contained approximately 1000 times more $\mathrm{H}_{2} \mathrm{SO}_{4}$ (and, presumably, accompanying metal contaminants) than the $\mathrm{pH} 5$ solutions, while the $\mathrm{HOOH}$ yields increased only by approximately a factor of 2 from $\mathrm{pH} 5$ to $\mathrm{pH} 2$.

\subsection{Temperature dependence of $\mathrm{HOOH}$ yields}

The work described above was all for aqueous solutions at $5^{\circ} \mathrm{C}$. As shown in Fig. 6a through $6 \mathrm{c}$, we also examined $\mathrm{HOOH}$ yields in solution at higher temperatures and in ice pellets at $-5^{\circ} \mathrm{C}$. Neither formaldehyde (at $\mathrm{pH} 2$ or 5) nor octanedioic acid showed a temperature dependence. In contrast, $\mathrm{HOOH}$ yields from the reaction of ${ }^{\circ} \mathrm{OH}$ with formate (Fig. 6b) did vary with temperature, with very similar results for both the $\mathrm{pH} 2$ and 5 samples. Oddly, the $\mathrm{HOOH}$ yields were greatest at the intermediate temperatures $(0.10$ to 0.13 at 5 and $10^{\circ} \mathrm{C}$ ) and lowest at both ends of the temperature range (approximately 0.03 at both -5 and $20^{\circ} \mathrm{C}$ ). For all three organic compounds in Fig. 6, the $\mathrm{HOOH}$ yields for ice samples $\left(-5^{\circ} \mathrm{C}\right)$ were not markedly different than values in solution: the average $\mathrm{HOOH}$ yield on ice was 0.12 at $\mathrm{pH}$ 2 and 0.050 at $\mathrm{pH} 5$. As in our solution experiments, it is unclear why $\mathrm{HOOH}$ production is more efficient in the more acidic samples. Chu and Anastasio (2003) found the ${ }^{\circ} \mathrm{OH}$ quantum yield from nitrate photolysis is lower in ice samples made from $\mathrm{pH} 2$ solutions compared to ice samples made from $\mathrm{pH} 5$ solutions, which should reduce $\mathrm{HOOH}$ production in our samples. In contrast, we found $\mathrm{HOOH}$ production is higher at the lower $\mathrm{pH}$ value.

In contrast, we saw a different behavior for the four other model organic compounds we illuminated in ice at $-5^{\circ} \mathrm{C}$ : 
phenylalanine ( $\mathrm{pH} 4.0$ ), sodium benzoate ( $\mathrm{pH} 5.0$ ), octanal (pH 5.6), and octanoic acid (pH 2.9 and $\mathrm{pH} 5.0)$. For these compounds in the presence of nitrate, there was no apparent production of $\mathrm{HOOH}$ on ice, although each formed $\mathrm{HOOH}$ in solution. Thus, in contrast to the results obtained with formaldehyde, formate, and octanedioic acid, it appears that reaction of $\cdot \mathrm{OH}$ with phenylalanine, benzoate, octanal, or octanoic acid does not produce $\mathrm{HOOH}$ in/on ice. In general, production of $\mathrm{HOOH}$ on ice is related to solubility, with more soluble compounds producing $\mathrm{HOOH}$ on ice, while less soluble compounds do not. This might be because the less soluble compounds are present at such low concentrations in liquid-like layers of the ice that they are minor sinks for the photoproduced ${ }^{\circ} \mathrm{OH}$. Alternately, the lack of $\mathrm{HOOH}$ production in ice samples containing one of these four organic compounds might also be because the organic compound and nitrate are partitioning to different compartments in the ice matrix; if these reactants are not collocated then the photoproduced ${ }^{\circ} \mathrm{OH}$ is unlikely to react with the organic.

\subsection{Comparison with previous work}

As noted above, the reaction of ${ }^{\circ} \mathrm{OH}$ with organics has been previously studied in aqueous systems, although with several important methodological differences compared to our work. First, ${ }^{\circ} \mathrm{OH}$ in past studies was generated by radiolysis of water, while we used simulated sunlight photolysis of nitrate. One complicating factor in the pulse or $\gamma$-radiolysis of water used in previous studies is that they directly produce $\mathrm{HO}_{2}^{*}$ and ${ }^{\circ} \mathrm{O}_{2}^{-}$. As shown in Reaction (R8) and (R9), these compounds can combine to produce $\mathrm{HOOH}$, possibly confounding experimental results, although a few of the past studies have examined the relative magnitude of the possible error. Second, the rate of ${ }^{\circ} \mathrm{OH}$ production in $\gamma$-radiolysis is typically much higher than our production rate; this difference in hydroxyl radical flux might change product yields by affecting the steady-state concentrations of intermediates such as peroxyl radicals. For example, the standard ${ }^{\circ} \mathrm{OH}$ production rate in the experiments of Stemmler and von Gunten (2000) was $245 \mathrm{nM} \mathrm{s}^{-1}$; in contrast, ours was $0.2 \mathrm{nM} \mathrm{s}^{-1}$, which is comparable to the rates of ${ }^{\circ} \mathrm{OH}$ production seen in ambient atmospheric aqueous drops (Anastasio and McGregor, 2001; Ervens et al., 2003; Faust and Allen, 1993).

Because previous authors typically did not correct measured $\mathrm{HOOH}$ yields for the direct radiolytic production of $\mathrm{HO}_{2}^{+}$, it is difficult to draw conclusions about the actual source of $\mathrm{HOOH}$ production in these experiments. Von Sonntag and Schuchmann (1997) summarize many of these studies, often giving $\mathrm{HOOH}$ yields adjusted for the primary radiolytic production of $\mathrm{HOOH}$, both directly and via $\mathrm{HO}_{2} /{ }^{\circ} \mathrm{O}_{2}^{-}$. $\mathrm{HOOH}$ yields in this subset of experiments ranged from 0.02 to 0.42 , with an average yield of approximately 0.22 . In our work at $\mathrm{pH} 5\left(5^{\circ} \mathrm{C}\right)$, we found a range of 0 to 0.24 , with an average of $0.12 \pm 0.05$ (95\% confidence interval). Given the
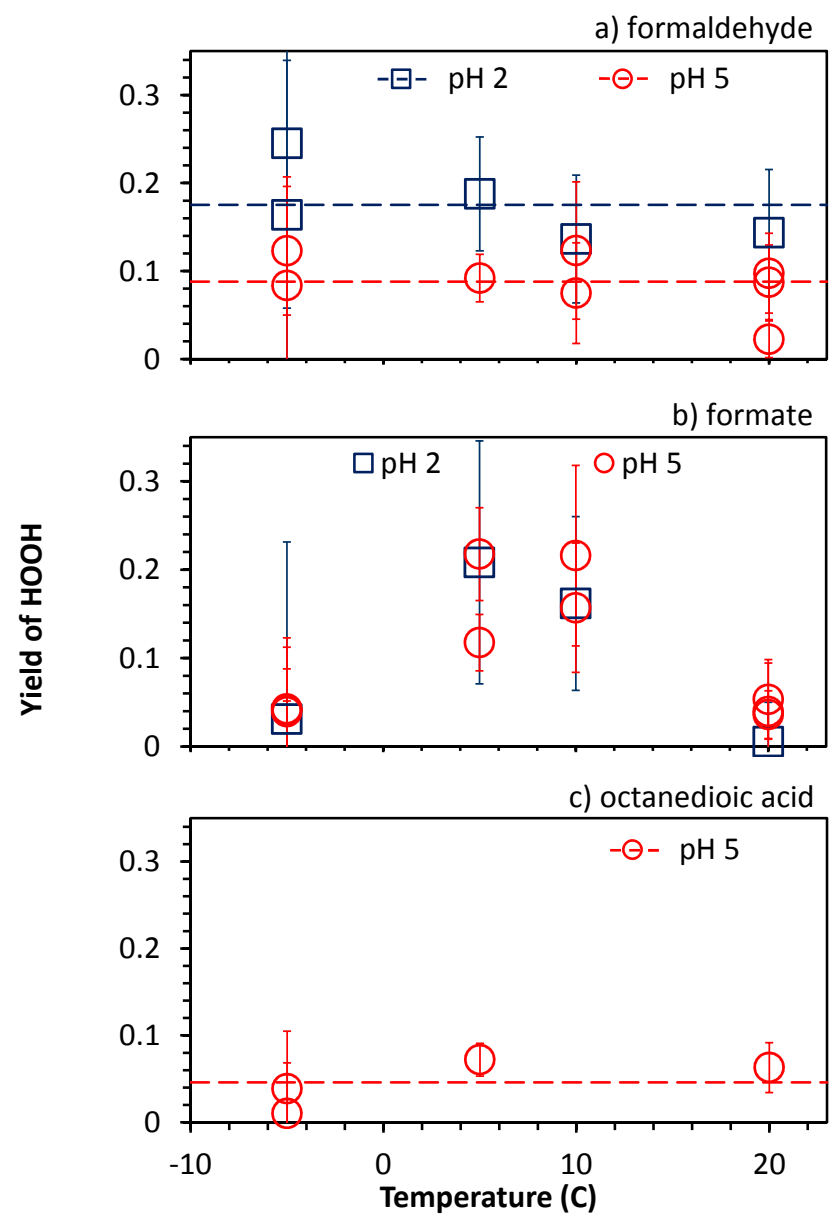

Fig. 6. Temperature dependence of the $\mathrm{HOOH}$ yield for three model compounds at $\mathrm{pH} 2$ (blue squares) and $\mathrm{pH} 5$ (red circles). The average $\mathrm{HOOH}$ yields (indicated by dashed horizontal lines) for formaldehyde were $0.18(\mathrm{pH} 2)$ and $0.088(\mathrm{pH} \mathrm{5)}$, while the average yield for octanedioic acid is $0.046(\mathrm{pH} \mathrm{5)}$. Error bars are the net indeterminate error (propagated standard error).

differences in experimental methods, and the likely impact of ${ }^{\bullet} \mathrm{OH}$ flux on $\mathrm{HOOH}$ yields described below, these results agree reasonably well.

One compound we studied, 2-butoxyethanol, was also studied previously using a $\gamma$-radiolysis method (Stemmler and von Gunten, 2000). Our $\mathrm{HOOH}$ yields from the reaction of ${ }^{\circ} \mathrm{OH}$ with 2-butoxyethanol $\left(20^{\circ} \mathrm{C}\right)$ are 0.09 at $\mathrm{pH} 6$ and 0.20 at $\mathrm{pH} 3$. Stemmler and von Gunten found ${ }^{\circ} \mathrm{OH}$ reaction with 2-butoxyethanol $(\mathrm{pH} 6$, temperature unspecified) produced $\mathrm{HOOH}$ and $\mathrm{HO}_{2}^{*}$ at yields of 0.17 and 0.25 , respectively. Assuming all of the $\mathrm{HO}_{2}^{*}$ disproportionated to form $\mathrm{HOOH}$, the net yield of $\mathrm{HOOH}$ from the ${ }^{\circ} \mathrm{OH}+2$ butoxyethanol reaction would be 0.30 . It is unclear why our value $(0.09$ at $\mathrm{pH} 6)$ is lower, but it is likely because of differences in the flux of ${ }^{\circ} \mathrm{OH}$ in the two experiments: Stemmler and von Gunten ran an additional experiment with a lower - $\mathrm{OH}$ production of $37 \mathrm{nM} \mathrm{s}^{-1}$ (instead of their standard flux of $245 \mathrm{nM} \mathrm{s}^{-1}$ ) and found a reduced overall yield of $\mathrm{HOOH}$. 
Unfortunately, it is not possible to quantify the $\mathrm{HOOH}$ yield in this second experiment because the authors did not determine the direct contribution of water radiolysis to $\mathrm{HOOH}$ for this condition. Nonetheless, it seems clear that lower ${ }^{\circ} \mathrm{OH}$ production rates lead to decreased yields of hydrogen peroxide; thus $\mathrm{HOOH}$ yields from our experiments are broadly consistent with results from previous studies.

\section{Implications and conclusions}

As atmospheric chemistry models such as CAPRAM (Ervens et al., 2003; Herrmann et al., 2005) continue to develop in sophistication and include additional reactions of - OH with organics, accurate assessment of reaction rates and product yields will be required to optimize model outputs. Comparing our range of $\mathrm{HOOH}$ yields to those from radiolytic studies suggests that past $\mathrm{HOOH}$ yields might be overestimated in previous work, and thus models that use these past results might be biased. In addition, our findings for some individual reactions indicate that $\mathrm{HOOH}$ yields can be less than expected based on common assumptions. For example, atmospheric chemistry models often assume $\alpha$-hydroxyperoxyl radicals will decompose with $100 \%$ efficiency to form an oxidized compound and a hydroperoxyl radical (see for example, the treatment of formaldehyde in Ervens et al., 2003). The resulting hydroperoxyl radical should readily form $\mathrm{HOOH}$ via Reaction (R9), especially when the solution $\mathrm{pH}$ is near the $\mathrm{pKa}$ of $\mathrm{HO}_{2}^{\circ}$. However, our experimental yield for $\mathrm{HOOH}$ from formaldehyde $(0.09$, $\mathrm{pH} 5,5^{\circ} \mathrm{C}$ ) is approximately $80 \%$ lower than the complete conversion (yield $=0.5$ ) anticipated from the reaction scheme in the model. This suggests that models might overestimate $\mathrm{HOOH}$ production from the ${ }^{\circ} \mathrm{OH}$-mediated oxidation of formaldehyde, and perhaps of other organics that form $\alpha$ hydroxyperoxyl radicals.

In addition, our work shows a significant $\mathrm{pH}$ dependence to $\mathrm{HOOH}$ production via ${ }^{\circ} \mathrm{OH}$ oxidation of organics that does not appear to be in current models of atmospheric aqueousphase chemistry. We found maximum $\mathrm{HOOH}$ yields of 0.35 $(\mathrm{pH} \mathrm{2})$ and $0.24(\mathrm{pH} \mathrm{5)}$. We believe these values represent reasonable upper-bound estimates for $\mathrm{HOOH}$ yields from 'OH reactions with organic compounds in atmospheric aqueous phases, and could be used in combination with the average yields presented earlier to validate model predictions.

We can use our estimated yields to evaluate the significance of $\mathrm{HOOH}$ formation from the reaction of ${ }^{\cdot} \mathrm{OH}$ with organic compounds in atmospheric aqueous phases. If appreciable concentrations of $\mathrm{HOOH}$ are found in the gas phase, mass transport will dominate, with $1 \mathrm{ppb}$ of gas phase $\mathrm{HOOH}$ delivering $500 \mu \mathrm{M} \mathrm{s}^{-1}$ to a 20 micron-diameter droplet. However, if $\mathrm{HOOH}$ is very low in the gas phase, aqueous-phase processes may be the dominant source of droplet $\mathrm{HOOH}$. In situ photoproduction of ${ }^{\bullet} \mathrm{OH}$ in natural, authentic cloud waters is on the order of $10 \mu \mathrm{M} \mathrm{h}^{-1}$ (Arakaki and Faust, 1998). Applying our average yield of 0.12 gives an expected formation rate of $\mathrm{HOOH}$ of $1.2 \mu \mathrm{Mh}^{-1}$ from ${ }^{\circ} \mathrm{OH}$-mediated reactions. In comparison, Anastasio et al. (1994) found $\mathrm{HOOH}$ production rates in authentic cloud waters of between 0.38 and $2.7 \mu \mathrm{Mh}^{-1}$, suggesting that reaction of ${ }^{\circ} \mathrm{OH}$ with organics in atmospheric aqueous phases could be a significant source of $\mathrm{HOOH}$ under some conditions.

Our results indicate that $\mathrm{HOOH}$ yields from the reaction of ${ }^{\circ} \mathrm{OH}$ with organics in ice are generally substantially lower than in atmospheric aqueous phases; thus assuming that reactions of ${ }^{\circ} \mathrm{OH}$ with organics in ice and snow proceed similarly to aqueous reactions will likely overestimate $\mathrm{HOOH}$ production rates. As noted earlier, four of the seven compounds tested in ice produced no $\mathrm{HOOH}$; depending on the mix of compounds in a particular snow pack, it may be that the rate of $\mathrm{HOOH}$ production from ${ }^{\circ} \mathrm{OH}$ radical attack on organics is zero. Looking only at the three compounds that conclusively produced $\mathrm{HOOH}$ in ice, the average yield was $0.12(\mathrm{pH} 2)$ and $0.050(\mathrm{pH} \mathrm{5)}$; these yields could be used to estimate $\mathrm{HOOH}$ production rates from ${ }^{\circ} \mathrm{OH}$ reaction with organics in ice. On ice, formaldehyde had the highest $\mathrm{HOOH}$ yields of the compounds we tested: 0.25 at $\mathrm{pH} 2$ and 0.13 at pH 5.

We can also use our ice data to address the second question we raised in our introduction: does recycling of $\mathrm{HOOH}$ through reaction of $\cdot \mathrm{OH}$ with organic compounds significantly extend the net lifetime of $\mathrm{HOOH}$ in snow and ice? To address this, we consider the net $\mathrm{HOOH}$ lifetime in snow for two cases: (1) with photolysis of $\mathrm{HOOH}$ only, and (2) with both $\mathrm{HOOH}$ photolysis and $\mathrm{HOOH}$ recycling via ${ }^{\circ} \mathrm{OH}$-mediated reactions of organics. Considering only $\mathrm{HOOH}$ photolysis, the rate constant for $\mathrm{HOOH}$ loss in surface snow at Summit, Greenland (summer solstice, midday), $j\left(\mathrm{HOOH} \rightarrow \mathrm{OH}\right.$ ), is $7 \times 10^{-3} \mathrm{~h}^{-1}$ (Chu and Anastasio, $2005)$, corresponding to a photolytic lifetime $(1 / j)$ for hydrogen peroxide of $143 \mathrm{~h}$.

Taking into account $\mathrm{HOOH}$ formation via ${ }^{\circ} \mathrm{OH}$ reactions with organic compounds, the net lifetime $(\tau)$ of $\mathrm{HOOH}$ is:

$$
\tau(\mathrm{HOOH})=\frac{[\mathrm{HOOH}]}{(1-2 \times \text { Yield }) \times R_{d}(\mathrm{HOOH})},
$$

where $[\mathrm{HOOH}]$ is the concentration of $\mathrm{HOOH}$ expressed on a bulk (melted snow) volume basis (typically $10 \mu \mathrm{M}$ for surface snow at Summit), $R_{d}(\mathrm{HOOH})$ is the rate of $\mathrm{HOOH}$ photolysis $\left(R_{d}(\mathrm{HOOH})=j(\mathrm{HOOH} \rightarrow \mathrm{OH}) \times[\mathrm{HOOH}]\right)$, and Yield is the yield of $\mathrm{HOOH}$ from reaction of ${ }^{\circ} \mathrm{OH}$ with snowgrain organics. Using an $\mathrm{HOOH}$ yield in ice of 0.10 (e.g., Fig. 6) results in a net lifetime of $\mathrm{HOOH}$ of $179 \mathrm{~h}$. Thus recycling of $\mathrm{HOOH}$ via the reaction of ${ }^{\circ} \mathrm{OH}$ with organics can increase the lifetime of $\mathrm{HOOH}$ by approximately $25 \%$. However, since it would take approximately 5 mo to bury surface snow at Summit (see Sect. 1), the modest impact of $\mathrm{HOOH}$ recycling appears insufficient to explain the preservation of $\mathrm{HOOH}$ in polar snowpacks. 


\section{Supplementary material related to this article is available online at: http://www.atmos-chem-phys.net/11/7209/2011/ acp-11-7209-2011-supplement.pdf.}

Acknowledgements. We thank Kelley Patten for assisting with experiments, and the National Science Foundation for funding this research (ANT-0636985).

Edited by: B. Ervens

\section{References}

Altieri, K. E., Turpin, B. J., and Seitzinger, S. P.: Oligomers, organosulfates, and nitrooxy organosulfates in rainwater identified by ultra-high resolution electrospray ionization FTICR mass spectrometry, Atmos. Chem. Phys., 9, 2533-2542, doi:10.5194/acp-9-2533-2009, 2009.

Anastasio, C. and McGregor, K. G.: Chemistry of fog waters in California's Central Valley: 1. In situ photoformation of hydroxyl radical and singlet molecular oxygen, Atmos. Environ., 35, 1079-1089, 2001.

Anastasio, C., Faust, B. C., and Allen, J. M.: Aqueous-phase photochemical formation of hydrogen-peroxide in authentic cloud waters, J. Geophys. Res.-Atmos., 99, 8231-8248, 1994.

Arakaki, T. and Faust, B. C.: Sources, sinks, and mechanisms of hydroxyl radical $(\mathrm{OH})$ photoproduction and consumption in authentic acidic continental cloud waters from Whiteface Mountain, New York: The role of the Fe(r) (r= II, III) photochemical cycle, J. Geophys. Res.-Atmos., 103, 3487-3504, 1998.

Barrie, L. A., Gregor, D., Hargrave, B., Lake, R., Muir, D., Shearer, R., Tracey, B., and Bidleman, T.: Arctic contaminants - sources, occurrence, and pathways, Sci. Total Environ., 122, 1-74, 1992.

Beine, H., and Anastasio, C.: The photolysis of flash-frozen dilute hydrogen peroxide solutions, J. Geophys. Res., 116, D14302, doi:10.1029/2010JD015531, 2011.

Bell, R. P., Rand, M. H., and Wynnejones, K. M. A.: Kinetics of the hydration of acetaldehyde, T. Faraday. Soc., 52, 1093-1102, 1956.

Bielski, B. H. J., Cabelli, D. E., Arudi, R. L., and Ross, A. B.: Reactivity of $\mathrm{HO}_{2}^{\bullet} /{ }^{\bullet} \mathrm{O}_{2}^{-}$radicals in aqueous-solution, J. Phys. Chem. Ref. Data, 14, 1041-1100, 1985.

Carlton, A. G., Turpin, B. J., Lim, H. J., Altieri, K. E., and Seitzinger, S.: Link between isoprene and secondary organic aerosol (SOA): Pyruvic acid oxidation yields low volatility organic acids in clouds, Geophys. Res. Lett., 33, L06822 doi:10.1029/2005g1025374, 2006.

Chameides, W. L. and Davis, D. D.: The free-radical chemistry of cloud droplets and its impact upon the composition of rain, J. Geophys. Res.-Ocean. Atmos., 87, 4863-4877, 1982.

Chameides, W. L. and Davis, D. D.: Aqueous-phase source of formic acid in clouds, Nature, 304, 427-429, 1983.

Christensen, H. C. and Gustafsson, R.: Radiolysis of aqueous toluene solutions, Acta. Chem. Scand., 26, 937-946, 1972.

Chu, L. and Anastasio, C.: Quantum yields of hydroxyl radical and nitrogen dioxide from the photolysis of nitrate on ice, J. Phys. Chem. A, 107, 9594-9602, doi:10.1021/jp0349132, 2003.
Chu, L. and Anastasio, C.: Formation of hydroxyl radical from the photolysis of frozen hydrogen peroxide, J. Phys. Chem. A, 109, 6264-6271, doi:10.1021/jp051415f, 2005.

Chu, L. and Anastasio, C.: Temperature and wavelength dependence of nitrite photolysis in frozen and aqueous solutions, Environ. Sci. Technol., 41, 3626-3632, doi:10.1021/es062731q, 2007.

Collett, J. L., Herckes, P., Youngster, S., and Lee, T.: Processing of atmospheric organic matter by California radiation fogs, Atmos. Res., 87, 232-241, doi:10.1016/j.atmosres.2007.11.005, 2008.

Deguillaume, L., Leriche, M., Monod, A., and Chaumerliac, N.: The role of transition metal ions on $\mathrm{HO}_{\mathrm{x}}$ radicals in clouds: a numerical evaluation of its impact on multiphase chemistry, Atmos. Chem. Phys., 4, 95-110, doi:10.5194/acp-4-95-2004, 2004.

Desideri, P. G., Lepri, L., Checchini, L., and Santianni, D.: Organic compounds in surface and deep antarctic snow, Int. J. Environ. Anal. Chem., 55, 33-46, 1994.

Dibb, J. E. and Arsenault, M.: Should not snowpacks be sources of monocarboxylic acids?, Atmos. Environ., 36, 2513-2522, 2002.

Dubowski, Y., Colussi, A. J., and Hoffmann, M. R.: Nitrogen dioxide release in the $302 \mathrm{~nm}$ band photolysis of spray-frozen aqueous nitrate solutions. Atmospheric implications, J. Phys. Chem. A, 105, 4928-4932, 2001.

Ervens, B., George, C., Williams, J. E., Buxton, G. V., Salmon, G. A., Bydder, M., Wilkinson, F., Dentener, F., Mirabel, P., Wolke, R., and Herrmann, H.: CAPRAM 2.4 (MODAC mechanism): An extended and condensed tropospheric aqueous phase mechanism and its application, J. Geophys. Res.-Atmos., 108, 4426, doi:10.1029/2002jd002202, 2003.

Faust, B. C.: Generation and use of simulated sunlight in photochemical studies of liquid solutions, Rev. Sci. Instrum., 64, $577-$ 578, 1993.

Faust, B. C.: Photochemistry of clouds, fogs, and aerosols, Environ. Sci. Technol., 28, A217-A222, 1994.

Faust, B. C. and Allen, J. M.: Aqueous-phase photochemical formation of hydroxyl radical in authentic cloudwaters and fogwaters, Environ. Sci. Technol., 27, 1221-1224, 1993.

Finlayson-Pitts, B. J. and Pitts, J. N.: Chemistry of the Upper and Lower Atmosphere: Theory, Experiments, and Applications, Academic Press, San Diego, 969 pp., 2000.

Fries, E., Sieg, K., Puttmann, W., Jaeschke, W., Winterhalter, R., Williams, J., and Moortgat, G. K.: Benzene, alkylated benzenes, chlorinated hydrocarbons and monoterpenes in snow/ice at Jungfraujoch $\left(46.6^{\circ} \mathrm{N}, 8.0^{\circ} \mathrm{E}\right)$ during CLACE 4 and 5, Sci. Total Environ., 391, 269-277, doi:10.1016/j.scitotenv.2007.10.006, 2008.

Galbavy, E. S., Anastasio, C., Lefer, B. L., and Hall, S. R.: Light penetration in the snowpack at Summit, Greenland: Part I Nitrite and hydrogen peroxide photolysis, Atmos. Environ., 41, 5077-5090, doi:10.1016/j.atmosenv.2006.04.072, 2007.

Galbavy, E. S., Ram, K., and Anastasio, C.: 2-Nitrobenzaldehyde as a chemical actinometer for solution and ice photochemistry, J. Photochem. Photobiol. A-Chem., 209, 186-192, doi:10.1016/j.jphotochem.2009.11.013, 2010.

Grannas, A. M., Shepson, P. B., and Filley, T. R.: Photochemistry and nature of organic matter in Arctic and Antarctic snow, Global Biogeochem. Cy., 18, GB1006, doi:Gb1006 10.1029/2003gb002133, 2004.

Grannas, A. M., Hockaday, W. C., Hatcher, P. G., Thompson, L. 
G., and Mosley-Thompson, E.: New revelations on the nature of organic matter in ice cores, J. Geophys. Res.-Atmos., 111, D04304 doi:10.1029/2005jd006251, 2006.

Grollert, C. and Puxbaum, H.: Lipid organic aerosol and snow composition at a high alpine site in the fall and the spring season and scavenging ratios for single compounds, Water Air Soil Poll., 117, 157-173, 2000.

Herrmann, H., Tilgner, A., Barzaghi, P., Majdik, Z., Gligorovski, S., Poulain, L., and Monod, A.: Towards a more detailed description of tropospheric aqueous phase organic chemistry: CAPRAM 3.0, Atmos. Environ., 39, 4351-4363, doi:10.1016/j.atmosenv.2005.02.016, 2005.

Howard, P. H. and Meylan, W. M.: Handbook of Physical Properties of Organic Chemicals, Lewis Publishers, Boca Raton, Fla., 1997.

Hutterli, M. A., McConnell, J. R., Bales, R. C., and Stewart, R. W.: Sensitivity of hydrogen peroxide $\left(\mathrm{H}_{2} \mathrm{O}_{2}\right)$ and formaldehyde (HCHO) preservation in snow to changing environmental conditions: Implications for ice core records, J. Geophys. Res.Atmos., 108, 4023, doi:10.1029/2002jd002528, 2003.

Hutterli, M. A., McConnell, J. R., Chen, G., Bales, R. C., Davis, D. D., and Lenschow, D. H.: Formaldehyde and hydrogen peroxide in air, snow and interstitial air at South Pole, Atmos. Environ., 38, 5439-5450, doi:10.1016/j.atmosenv.2004.06.003, 2004.

Jacobi, H. W., Annor, T., and Quansah, E.: Investigation of the photochemical decomposition of nitrate, hydrogen peroxide, and formaldehyde in artificial snow, J. Photochem. Photobiol. AChem., 179, 330-338, doi:10.1016/j.jphotochem.2005.09.001, 2006.

Kok, G. L., McLaren, S. E., and Staffelbach, T. A.: HPLC determination of atmospheric organic hydroperoxides, J. Atmos. Ocean. Tech., 12, 282-289, 1995.

Laniewski, K., Boren, H., and Grimvall, A.: Identification of volatile and extractable chloroorganics in rain and snow, Environ. Sci. Technol., 32, 3935-3940, 1998.

Legrand, M. and Deangelis, M.: Origin and variations of light carboxylic acids in polar precipitation, J. Geophys. Res.-Atmos., 100, 1445-1462, 1995.

Legrand, M. and Mayewski, P.: Glaciochemistry of polar ice cores: A review, Rev. Geophys., 35, 219-243, 1997.

Lelieveld, J. and Crutzen, P. J.: Influences of cloud photochemical processes on tropospheric ozone, Nature, 343, 227-233, 1990.

Lelieveld, J. and Crutzen, P. J.: The role of clouds in tropospheric photochemistry, J. Atmos. Chem., 12, 229-267, 1991.

Mazzoleni, L. R., Ehrmann, B. M., Shen, X. H., Marshall, A. G., and Collett, J. L.: Water-Soluble Atmospheric Organic Matter in Fog: Exact Masses and Chemical Formula Identification by Ultrahigh-Resolution Fourier Transform Ion Cyclotron Resonance Mass Spectrometry, Environ. Sci. Technol., 44, 36903697, doi:10.1021/es903409k, 2010.

Moller, D.: Atmospheric hydrogen peroxide: Evidence for aqueous-phase formation from a historic perspective and a oneyear measurement campaign, Atmos. Environ., 43, 5923-5936, doi:10.1016/j.atmosenv.2009.08.013, 2009.

Nese, C., Schuchmann, M. N., Steenken, S., and von Sonntag, C.: Oxidation vs. fragmentation in radiosensitization. Reactions of alpha-alkoxylalkyl radicals with 4-nitrobenzonitrile and oxygen. A pulse radiolysis and product analysis study, J. Chem. Soc. Perk. T 2, 1037-1044, 1995.

Pan, X.-M., Schuchmann, M. N., and von Sonntag, C.: Hydroxyl- radical-induced oxidation of cyclohexa-1,4-diene by $\mathrm{O}_{2}$ in aqueous solution. A pulse radiolysis and product study, J. Chem. Soc. Perk. T 2, 1021-1028, 1993a.

Pan, X.-M., Schuchmann, M. N., and von Sonntag, C.: Oxidation of benzene by the $\mathrm{OH}$ radical. A product and pulse radiolysis story in oxygenated aqueous solution, J. Chem. Soc. Perk. T 2, 289-197, 1993b.

Perrier, S., Houdier, S., Domine, F., Cabanes, A., Legagneux, L., Sumner, A. L., and Shepson, P. B.: Formaldehyde in Arctic snow. Incorporation into ice particles and evolution in the snowpack, Atmos. Environ., 36, 2695-2705, 2002.

Piesiak, A., Schuchmann, M. N., Zegota, H., and von Sonntag, C.: beta-hydroyethylperoxyl radicals: a study of the gammaradiolysis and pulse radiolysis of ethylene in oxygenated aqueous solutions, Z. Naturforsch, 39B, 1262-1267, 1984.

Qiu, R., Green, S. A., Honrath, R. E., Peterson, M. C., Lu, Y., and Dziobak, M.: Measurements of $J\left(\mathrm{NO}_{3}^{-}\right)$in snow by nitratebased actinometry, Atmos. Environ., 36, 2563-2571, 2002.

Ram, K. and Anastasio, C.: Photochemistry of phenanthrene, pyrene, and fluoranthene in ice and snow, Atmos. Environ., 43, 2252-2259, doi:10.1016/j.atmosenv.2009.01.044, 2009.

Satsumabayashi, H., Nishizawa, H., Yokouchi, Y., and Ueda, H.: Pinonaldehyde and some other organics in rain and snow in central Japan, Chemosphere, 45, 887-891, 2001.

Schuchmann, H. P. and von Sonntag, C.: Methylperoxyl radicals: a study of the gamma-radiolysis of methane in oxygenated aqueous solutions, Z. Naturforsch, 39B, 217-221, 1984.

Schuchmann, M. N. and von Sonntag, C.: Radiation chemistry of carbohydrates. Part 14. Hydroxyl-radical induced oxidation of dglucose in oxygenated aqueous solution, J. Chem. Soc. Perk. T 2, 1958-1963, 1977.

Schuchmann, M. N. and von Sonntag, C.: Radiation chemistry of alcohols 22. Hydroxyl radical-induced oxidation of 2-methyl-2propanol in oxygenated aqueous solution. A product and pulse radiolysis study J. Phys. Chem., 83, 780-784, 1979.

Schuchmann, M. N. and von Sonntag, C.: Hydroxyl radical induced oxidation of diethyl ether in oxygenated aqueous solution. A product and pulse radiolysis study, J. Phys. Chem., 86, 19952000, 1982.

Schuchmann, M. N. and von Sonntag, C.: The radiolysis of uracil on oxygenated aqueous solutions. A study by product analysis and pulse radiolysis, J. Chem. Soc. Perk T 2, 1525-1531, 1983.

Schuchmann, M. N., Zegota, H., and von Sonntag, C.: Acetate peroxyl radicals, $\mathrm{OOCH}_{2} \mathrm{CO}_{2}^{-}$: a study on the gamma-radiolysis and pulse radiolysis or acetate in oxygenated aqeous solutions, Z. Naturforsch, 40B, 215-221, 1985.

Schuchmann, M. N. and von Sonntag, C.: The rapid hydration of the acetyl radical. A pulse radiolysis study of acetaldehyde in aqueous solution, J. Am. Chem. Soc., 110, 5698-5701, 1988.

Schuchmann, M. N., Schuchmann, H. P., and von Sonntag, C.: Hydroxyl radical induced oxidation of acetaldehyde dimethyl acetal in oxygenated aqueous solution. Rapid ${ }^{\circ} \mathrm{O}_{2}^{-}$release from the $\mathrm{CH}_{3} \mathrm{C}\left(\mathrm{OCH}_{3}\right)_{2} \mathrm{O}_{2}$ radical, J. Am. Chem. Soc., 112, 403-407, 1990.

Schuchmann, M. N., Schuchmann, H. P., and von Sonntag, C.: Oxidation of hydromalonic acid by $\mathrm{OH}$ radicals in the presence and in the absence of molecular oxygen. A pulse-radiolysis and product study, J. Phys. Chem., 99, 9122-9129, 1995.

Sigg, A. and Neftel, A.: Evidence for a 50-percent increase in $\mathrm{H}_{2} \mathrm{O}_{2}$ 
over the past 200 years from a Greenland ice core, Nature, 351, 557-559, 1991.

Sigma-Aldrich: http://www.sigmaaldrich.com/etc/medialib/docs/ Sigma-Aldrich/Product_Information_Sheet/p6148pis.Par.0001. File.tmp/p6148pis.pdf (last access: 30 January 2011), 2010.

Stefanic, I., Bonifacic, M., Asmus, K. D., and Armstrong, D. A.: Absolute rate constants and yields of transients from hydroxyl radical and $\mathrm{H}$ atom attack on glycine and methyl-substituted glycine anions, J. Phys. Chem. A, 105, 8681-8690, 2001.

Stemmler, K. and von Gunten, U.: OH radical-initiated oxidation of organic compounds in atmospheric water phases: part 1. Reactions of peroxyl radicals derived from 2-butoxyethanol in water, Atmos. Environ., 34, 4241-4252, 2000.

Tan, Y., Perri, M. J., Seitzinger, S. P., and Turpin, B. J.: Effects of Precursor Concentration and Acidic Sulfate in Aqueous Glyoxal-OH Radical Oxidation and Implications for Secondary Organic Aerosol, Environ. Sci. Technol., 43, 8105-8112, doi:10.1021/es901742f, 2009.

Ulanski, P., Bothe, E., Rosiak, J., and von Sonntag, C.: Radiolysis of the poly(acrylic acid) model 2,4-dimethylglutaric acid: a pulse radiolysis and product study, J. Chem. Soc. Perk. T 2, 512, 1996.

von Sonntag, C. and Schuchmann, H.-P.: Peroxyl Radicals in Aqueous Solutions, in: Peroxyl Radicals, edited by: Alfassi, Z. B., John Wiley and Sons, Chichester, 1997.

Warneck, P. and Wurzinger, C.: Product quantum yields for the 305$\mathrm{nm}$ photodecomposition of $\mathrm{NO}_{3}^{-}$in aqueous solution, J. Phys. Chem., 92, 6278-6283, 1988.
Zegota, H., Schuchmann, M. N., and von Sonntag, C.: Cyclopentylperoxyl and cyclohexylperoxyl radicals in aqueous solution. A study by product analysis and pulse radiolysis, J. Phys. Chem., 88, 5589-5593, 1984.

Zellner, R., Exner, M., and Herrmann, H.: Absolute OH quantum yields in the laser photolysis of nitrate, nitrite, and dissolved $\mathrm{H}_{2} \mathrm{O}_{2}$ at 308 and $351 \mathrm{~nm}$ in the temperature range $278-353 \mathrm{~K}$, J. Atmos. Chem., 10, 411-425, 1990.

Zhang, Q. and Anastasio, C.: Chemistry of fog waters in California's Central Valley - Part 3: concentrations and speciation of organic and inorganic nitrogen, Atmos. Environ., 35, 5629-5643, 2001.

Zhang, Q. and Anastasio, C.: Free and combined amino compounds in atmospheric fine particles $\left(\mathrm{PM}_{2.5}\right)$ and fog waters from Northern California, Atmos. Environ., 37, 2247-2258, doi:10.1016/s1352-2310(03)00127-4, 2003.

Zhao, J., Levitt, N. P., and Zhang, R. Y.: Heterogeneous chemistry of octanal and 2,4-hexadienal with sulfuric acid, Geophys. Res. Lett., 32, L09802, doi:10.1029/2004g1022200, 2005.

Zhou, X. L., Davis, A. J., Kieber, D. J., Keene, W. C., Maben, J. R., Maring, H., Dahl, E. E., Izaguirre, M. A., Sander, R., and Smoydzyn, L.: Photochemical production of hydroxyl radical and hydroperoxides in water extracts of nascent marine aerosols produced by bursting bubbles from Sargasso seawater, Geophys. Res. Lett., 35, L20803, doi:10.1029/2008gl035418, 2008. 